\title{
Impact of Humic Acid Amendments on Alleviating the Harmful Effects of Cadmium in Radish and Bean Plants
}

\author{
Elkhatib, H.A. S.M.Gabr and S.H. Brengi ${ }^{1}$
}

\begin{abstract}
The present study is focused on the role of humic acid on alleviating the harmful effect of cadmium on growth, yield and some physiological processes in radish and bean plants. Two Pot experiments were carried on summer seasons of 2010 and 2011 at the Experimental Farm, ElBostan, Faculty of agriculture, Damanhour University, Egypt. Four different levels of cadmium (0, 25, 50 and 75 ppm) and two levels of humic acid (control and $150 \mathrm{mg} / \mathrm{kg}$ soil) were used in minimizing the harmful effects of cadmium on radish 'Balady' and common bean 'Giza 4' plants. The obtained results revealed that all the assigned concentrations of cadmium induced significant decrease in all the studied vegetative growth characters (plant fresh and dry weight, number of leaves and total leaf area /plant) , yield characters (number of green pods, yield of green and dry pods, seed yield/plant of bean and root characters of radish plants) and leaves chemical constituents (Chlorophyll, nitrogen, phosphorous and potassium) compared to control in both seasons. On contrary increasing cadmium concentration in the soil increased cadmium content in root, leave and seeds of common bean and radish plants as compared to control in both seasons. Common bean plants was more sensitive than radish plants to elevated levels of $\mathrm{Cd}$ in growing media. Humic acid treatments was able to minimize the harmful effect of cadmium in all the studied characters and improve the concentrations of photosynthetic pigments, nitrogen, phosphorous and potassium in leaves of common bean and radish plants grown in cadmium polluted soils as well as decreased cadmium content in root, stem, leave and seeds of common bean and radish plants as compared to control .
\end{abstract}

Key words: common bean, Radish, Pollution, Cadmium, humic acid Vegetative growth, Yield, chemical composition.

\section{INTRODUCTION}

The contamination of soils by heavy metals has become one of the most important environmental problems in developed and developing countries. Research on $\mathrm{Cd}$ pollution has received increasing international attention as $\mathrm{Cd}$ is toxic and can cause severe human health problems, therefore Cadmium $(\mathrm{Cd})$ is often referred as the metal of the 20th Century. It is listed by the US Environmental Protection Agency as one of the 126 priority contaminants and as a human carcinogen by the International Agency for Research on Cancer (IARC, 1994). The Cd is added to the environment by different sources like power station, metal working, urban runoff, mining operation, intensive agriculture, and sludge dumping (Sandalio et al. 2001).

The effects of Cd toxicity are reported at all levels .It causes deterioration of many physiological processes, such as the reduction in the number of chloroplasts (inhibition of chlorophyll synthesis and changes of the antioxidant status (Somashekaraiah et al. 1992). Affects photosynthesis, respiration, transpiration rate and alters enzymatic activities (Chen et al., 2003), disturbs plant water-relationships and ionic relations, induces free radicals formation and affects the uptake and distribution of micro- and macronutrients concentrations in the tissues (Wahid et al., 2007). Plant species and cultivars differ widely in their ability to absorb, accumulate and tolerate heavy metals. However, the amount of $\mathrm{Cd}$ deposited into the root, shoot and inter-veins of leaves considerably differed among different species (Wahid et al.,2008).

Leach ability and plant uptake of cadmium $(\mathrm{Cd})$, and other heavy metals depend on the mobility and availability of the metals in the soil, which in turn are affected by contents of solid and dissolved organic matter.

Humic acids are among the most widely distributed organic materials in soils and sediments (Stevenson 1994). Studies on the effects of humic acids on plant growth can be grouped into: indirect effects on physiological, chemical and biological properties of the soil and improve soil fertility (Ohta et al., 2004). and direct effects on physiological processes of plant through enhancement of root initiation and increasing root growth (Pettit, 2004), stimulating uptake of macronutrients, such as nitrogen, phosphorus, and potassium and micronutrients such as, $\mathrm{Fe}, \mathrm{Zn}, \mathrm{Cu}$ and Mn (Chen et al., 1999). They have also a profound effect on the speciation and mobility of heavy metals in soils and aquifers because they carry a large number of functional groups on their surface such as carboxyl and phenolic $\mathrm{OH}$ functional groups, therefore, it provides organic macromolecules with an important role in the transport, bioavailability and solubility of heavy metals (Chen and Zhu, 2006).

\footnotetext{
${ }^{1}$ Hortculture Department, Faculty of Agriculture,

Damanhour University.

Received May 04, 2013, Accepted June 30, 2013
} 
Little is known about the effects of humic acid on alleviating the harmful effect of cadmium on plant growth and some physiological characters. Therefore, the objective of this work was to investigate the toxic effects of cadmium on growth, ion content as well as certain physiological aspects of radish (Raphanus sativus, L.) and bean (Phaseolus vulgaris L.). plants. Another objective is using humic acid to assess if its application could provide useful recovery the adverse effects of cadmium toxicity or on the other hand to assess the alleviative effects of humic acid on $\mathrm{Cd}$ impacted radish and bean plants.

\section{MATERIALS AND METHODS}

\section{1- Experiments}

During the two consecutive summer seasons of 2010 and 2011 at the Experimental Farm of El-Bostan, Faculty of Agriculture Damanhour University, Two pot experiments were conducted to determine the effect of cadmium pollution at concentrations of $0,25,50$ and 75 ppm on vegetative growth, yield and chemical composition of common bean 'Giza 4'and radish 'Balady' plants as well as to investigate the alleviative effects of humic acid (150 mg/kg soil) on Cd-impacted radish and bean plants. The varieties and the concentrations of cadmium and humic acid were selected after performing a pilot experiment based on growth and morphological attributes (length, fresh and dry weight of shoot, root and leaf area), which led to the selection of radish to be highly tolerant and beans as highly sensitive (data not shown).
A bulk sample of the top layer $(0-20 \mathrm{~cm})$ of a silt clay soil was collected from Experimental Farm of El-Bostan and physical and chemical characteristics of the soil (Table 1) were determined before sowing according to the methods reported by Page et al. (1982). Cadmium was determined according to the method mentioned by Jackson, (1973) and measured by atomic absorption spectrophotometer (AAS).

\section{2- Design and establishment of the experiment}

The experiment was carried out in plastic pots of 35 $\mathrm{cm}$ inner diameter filled with $14 \mathrm{~kg}$ of the soil. Cadmium was amended into the soil in the form of cadmium chloride $\left(\mathrm{CdCl}_{2} \cdot \mathrm{H}_{2} \mathrm{O}\right)$ at $\mathrm{Cd}$ concentrations of $0,25,50,75 \mathrm{ppm}$. The soils with different concentrations of $\mathrm{Cd}$ were brought to field capacity and allowed to air dry to insure Cd-soil equilibrium. Five seeds of common bean 'Giza 4' and 9 seeds of radish ,Balady, obtained from Agricultural Research Center, Giza, Egypt were sown on April 26th in the first season of 2010 and on 2nd of May in the second season of 2011 in each pot. Pots were irrigated with tap water whenever it was needed to keep the moisture in soil at about $70 \%$ of the total water holding capacity during the experimental period.

Three weeks after sowing, radish plants were thinned to 7 uniform young plants per pot. Calcium superphosphate $\left(15.5 \% \mathrm{P}_{2} \mathrm{O}_{5}\right)$ was mixed with the soil prior to sowing at the rate of $4 \mathrm{~g} /$ pot. While, ammonium nitrate $(33 \% \mathrm{~N})$ and potassium sulphate $\left(48 \% \quad \mathrm{~K}_{2} \mathrm{O}\right)$ were added with irrigation water after thinning at the rate of $1.5 \mathrm{~g} /$ pot for each fertilizer.

\section{Table 1. Some chemical and physical characteristics of the soil used in the experiments}

Physical analysis

Clay

Sand $(\%)$

49

Soil texture

Chemical properties

$\mathrm{pH} \quad 8.1$

$\mathrm{EC}(\mathrm{mmohs})$

1.2

$\mathrm{CaCO}_{3}$

2.081

Macro- elements (ppm)

Total $\mathrm{N}$

117

Total P

317

Total K

431.12

Micro- elements (ppm)

$\mathrm{Mn}$

26.8

$\mathrm{Fe}$

9.72

$\mathrm{Zn}$

2.7

$\mathrm{Cu}$

2.1

$\mathrm{Cd}$

0.16 
Other agricultural practices were done according to the recommended practices. Humic acid at the rate of $150 \mathrm{mg} / \mathrm{kg}$ soil as potassium humate were added to soil before sowing. The pots were arranged in a complete randomized block design in a split plots system with three replicates. Cadmium at the concentrations of $0.0,25,50$ and $75 \mathrm{ppm}$ occupied the main plots; whereas, humic acid treatment of $(150 \mathrm{mg} / \mathrm{kg}$ soil $)$ as well as the control were assigned at random in the subplots. Each treatment contained 5 pots.

\section{3- Harvesting and Plant Analysis:}

At harvest time plants were collected from each treatment and Plant samples were collected for the measurement of various growth parameters: In radish plants, roots weight, length and thickness and shoots fresh and dry weights as well as leaves number and area per plant in addition to seeds yield plant ${ }^{-1}$ were recorded meanwhile In bean plants, number of leaves per plant, leaves area $\left(\mathrm{cm}^{2}\right)$ per plant by using the weight method as described by Fayed (1997), fresh and dry weight plants $^{-1}$, number of green pods plant ${ }^{-1}$ and green pods yield plant $^{-1}(\mathrm{~g})$ were recorded. For determination dry matter contents, plants were dried at $70 \mathrm{C}^{\circ}$ in an electric oven for at least 48 hours and weighed accurately.

Plants were finally harvested after complete maturity (90 days) then dry pods yield plant $^{-1}(\mathrm{~g})$ and dry seed yield plant $^{-1}(\mathrm{~g})$ were recorded. The harvested plants were washed thoroughly with tap water and then with deionized water. The plant samples and dry seeds were oven dried at $70 \mathrm{C}^{\circ}$ for 48 hours to constant weight. The oven-dried samples were ground in a mill with stainless steel blades and wet digestion procedure was performed according to Chapman and Pratt (1978). The Cd concentrations of the samples were determined with Atomic Absorption spectrophotometer according to Cottenie et al., (1982). Phosphorus percentage of dry seeds was determined calorimetrically as reported by Jackson, (1967). Potassium percentage of dry seeds was determined by flame photometer as described by Brown and Lilliand (1946). The nitrogen contents of dry seeds were determined using micro-kjeldahl method according to Ling (1963).Chlorophyll A, B were determined calorimetrically in $80 \%$ acetone extracts according to Wettstein (1957).

\section{4- Statistical analysis:}

All obtained data were statistically analyzed using SAS software program (1996). Comparisons among the means of different treatments were achieved using the revised least significant difference procedure at $P=0.05$ level as illustrated by Al-Rawy and Khalf-Allah (1980).

\section{RESULTS AND DISCUSSION}

\section{Growth parameter:}

Data concerning the influence of different levels of $\mathrm{Cd}$ on the plant fresh weight, leaves number and leaves area of radish and common bean plants are given in Tables (2 and 3). It is quite clear that increasing the levels of applied Cd significantly decreased the plant fresh weight, plant dry weight, leaves number and leaves area of radish and common bean plants. The reduction being 29.4 and $29.53 \%$ in plant fresh weight, 20.42and $21.08 \%$ in plant dry weight, 19.48 and $25.19 \%$ in leaves number and 52.99 and $46.3 \%$ in leaves area for radish plants at Cd levels of $75 \mathrm{ppm}$ in the first and second seasons respectively, as compared to control when no addition of cadmium. While, the corresponding values for common bean plants were 26.36 and $27.02 \%$ in plant fresh weight, 28.03 and 27.76 in plant dry weight, 34.74 and $34.44 \%$ in leaves number, 59.61 and 59.87 in leaves area in the same order.

The decrease in growth parameter was more obvious in common bean than in radish plants, indicating the harmful effect of this metal on common bean rather than on radish plants. These results are in agreement with those reported by Fouda and Arafa (2002) on soybean. They found that cadmium treatment decreased plant height, leaf area and dry weight of shoot plant ${ }^{-1}$. Some investigators confirmed these findings on other plant species, for instance, Gadallah (1995) working on sunflower stated that heavy metal toxicity appeared in the reduction of plant height and dry mass accumulation. Likewise, El-Ghinbihi (2000) reported that leaves fresh weight and leaf area of common bean plants were decreased by cadmium treatments. Also Varalakshmi and Ganeshamurthy (2013) found that increasing cadmium levels significantly decreased shoot fresh weight of radish plants. The inhibitory effect of $\mathrm{Cd}$ on plant growth could be explained on the basis of its effect on the biological processes and nutritional disturbances as reported by Sheoran et al. (1990) who revealed that $\mathrm{Cd}$ can inhibit photosynthesis in various ways: through decreased stomatal conductance, reduction of photosynthetic pigments, inhibition of chloroplast activity, and indirectly by affecting other metabolic activity. Cadmium has been shown to cause many morphological, physiological and biochemical changes in plants, such as growth inhibition, and water imbalance (Benavides et al., 2005). Moreover, cadmium at high levels may inhibit root and shoot growth directly by inhibiting cell division or cell elongation, or a combination of both, resulting in limited exploration of the soil volume for uptake and translocation of nutrients and water (Khan and Frakland, 1983). 
Table 2. Plant fresh and dry weight, leaves number and leaves area of radish plants as affected by different levels of cadmium and humic acid during the two growing seasons of 2010 and 2011

\begin{tabular}{|c|c|c|c|c|c|c|c|c|c|}
\hline & & \multicolumn{2}{|c|}{$\begin{array}{l}\text { Plant fresh weight } \\
\text { (gm) }\end{array}$} & \multicolumn{2}{|c|}{$\begin{array}{c}\text { Plant dry weight } \\
\text { (gm) }\end{array}$} & \multicolumn{2}{|c|}{ Leaves number } & \multicolumn{2}{|c|}{$\begin{array}{c}\text { Leaves area } \\
\left(\mathrm{cm}^{2}\right)\end{array}$} \\
\hline & & $\begin{array}{l}2010 \\
\text { season }\end{array}$ & $\begin{array}{l}2011 \\
\text { season }\end{array}$ & $\begin{array}{l}2010 \\
\text { season }\end{array}$ & $\begin{array}{l}2011 \\
\text { season }\end{array}$ & $\begin{array}{l}2010 \\
\text { season }\end{array}$ & $\begin{array}{l}2011 \\
\text { season }\end{array}$ & $\begin{array}{l}2010 \\
\text { season }\end{array}$ & $\begin{array}{l}2011 \\
\text { season }\end{array}$ \\
\hline \multirow{4}{*}{ 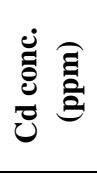 } & 0 & $118.01 \mathrm{~A}$ & $115.51 \mathrm{~A}$ & $12.88 \mathrm{~A}$ & $13.11 \mathrm{~A}$ & $6.83 \mathrm{~A}$ & $6.67 \mathrm{~A}$ & $1295.12 \mathrm{~A}$ & $1137.05 \mathrm{~A}$ \\
\hline & 25 & $93.53 \mathrm{~B}$ & $95.68 \mathrm{~B}$ & $10.4 \mathrm{~B}$ & $11.25 \mathrm{~B}$ & $6.83 \mathrm{~A}$ & $6.44 \mathrm{~A}$ & $886.50 \mathrm{~B}$ & $883.99 \mathrm{~B}$ \\
\hline & 50 & $90.67 \mathrm{~B}$ & $89.34 \mathrm{C}$ & $10.08 \mathrm{~B}$ & $10.14 \mathrm{C}$ & $6.17 \mathrm{~B}$ & $5.77 \mathrm{~B}$ & $777.57 \mathrm{C}$ & $781.40 \mathrm{C}$ \\
\hline & 75 & $83.31 \mathrm{C}$ & $81.40 \mathrm{D}$ & $9.27 \mathrm{C}$ & $9.47 \mathrm{D}$ & $5.50 \mathrm{C}$ & $4.99 \mathrm{C}$ & $608.87 \mathrm{D}$ & $609.64 \mathrm{D}$ \\
\hline \multirow{2}{*}{ 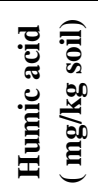 } & 0 & $89.81 \mathrm{~B}$ & $88.25 \mathrm{~B}$ & $9.86 \mathrm{~B}$ & $10.31 \mathrm{~B}$ & $5.83 \mathrm{~B}$ & $5.44 \mathrm{~B}$ & $871.94 \mathrm{~B}$ & $840.20 \mathrm{~B}$ \\
\hline & 150 & $102.95 \mathrm{~A}$ & $102.72 \mathrm{~A}$ & $11.46 \mathrm{~A}$ & $11.67 \mathrm{~A}$ & $6.83 \mathrm{~A}$ & $6.50 \mathrm{~A}$ & $912.09 \mathrm{~A}$ & $865.84 \mathrm{~A}$ \\
\hline
\end{tabular}

*Values having a common alphabetical letter (s), do not significantly differ, using the revised L.S.D. test at P=0.05.

Table 3. Plant fresh weight, leaves number per plant, leaves area of Common bean plants as different levels of cadmium and humic acid during the two growing seasons of 2010 and 2011

\begin{tabular}{|c|c|c|c|c|c|c|c|c|c|}
\hline & & \multicolumn{2}{|c|}{$\begin{array}{c}\text { Plant fresh weight } \\
(\mathrm{gm})\end{array}$} & \multicolumn{2}{|c|}{$\begin{array}{c}\text { Plant dry weight } \\
\text { (gm) }\end{array}$} & \multicolumn{2}{|c|}{ Leaves number } & \multicolumn{2}{|c|}{$\begin{array}{c}\text { Leaves area } \\
\left(\mathrm{cm}^{2}\right)\end{array}$} \\
\hline & & $\begin{array}{c}2010 \\
\text { season } \\
\end{array}$ & $\begin{array}{c}2011 \\
\text { season } \\
\end{array}$ & $\begin{array}{c}2010 \\
\text { season } \\
\end{array}$ & $\begin{array}{c}2011 \\
\text { season } \\
\end{array}$ & $\begin{array}{c}2010 \\
\text { season } \\
\end{array}$ & 2011 & $\begin{array}{c}2010 \\
\text { season } \\
\end{array}$ & $\begin{array}{c}2011 \\
\text { season } \\
\end{array}$ \\
\hline \multirow{4}{*}{ 异 } & 0 & $69.60 \mathrm{~A}$ & $68.33 \mathrm{~A}$ & $15.08 \mathrm{~A}$ & $14.80 \mathrm{~A}$ & $15.66 \mathrm{~A}$ & $15.33 \mathrm{~A}$ & $1031.10 \mathrm{~A}$ & $1011.89 \mathrm{~A}$ \\
\hline & 25 & $64.63 \mathrm{~B}$ & $62.81 \mathrm{~B}$ & $14.75 \mathrm{~B}$ & $14.23 \mathrm{~B}$ & $13.50 \mathrm{~B}$ & $13.11 \mathrm{~B}$ & $729.33 \mathrm{~B}$ & $698.78 \mathrm{~B}$ \\
\hline & 50 & $58.30 \mathrm{C}$ & $58.71 \mathrm{C}$ & $13.33 \mathrm{C}$ & $13.09 \mathrm{C}$ & $11.83 \mathrm{C}$ & $11.68 \mathrm{C}$ & $572.50 \mathrm{C}$ & $537.18 \mathrm{C}$ \\
\hline & 75 & $51.25 \mathrm{D}$ & $49.87 \mathrm{D}$ & $12 \quad \mathrm{D}$ & $11.68 \mathrm{D}$ & $10.22 \mathrm{D}$ & $10.05 \mathrm{D}$ & 416.50 D & 406.07 D \\
\hline \multirow{2}{*}{ 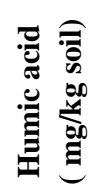 } & 0 & $57.57 \mathrm{~B}$ & $56.88 \mathrm{~B}$ & $13.15 \mathrm{~B}$ & $12.938 \mathrm{~B}$ & $11.61 \mathrm{~B}$ & $11.48 \mathrm{~B}$ & $573.55 \mathrm{~B}$ & $567.52 \mathrm{~B}$ \\
\hline & 150 & $64.32 \mathrm{~A}$ & $62.98 \mathrm{~A}$ & $14.43 \mathrm{~A}$ & $13.97 \mathrm{~A}$ & $14.00 \mathrm{~A}$ & $13.61 \mathrm{~A}$ & $801.17 \mathrm{~A}$ & $759.44 \mathrm{~A}$ \\
\hline
\end{tabular}

*Values having a common alphabetical letter ( $\mathrm{s}$, do not significantly differ, using the revised L.S.D. test at $\mathrm{P}=0.05$.

However, these results are in accordance with Hashida (1961) who stated that honey is a valuable agent that can be added to mulberry leaves and those reported by Nagda El-Sayed (1989 and 1994), Govindan et al., (1988), El-Karaksy and Idriss (1990), Muniandy et al., (1995), Sarker et al (1995) and Manoharan (1997) who found that the detected parameters of fitness component of Philosamia ricini Boisd or Bombyx mori L. larvae were significantly affected by the evaluated food additives. Nagda El- Sayed et al (1996) found that the black cumin at 10 and $20 \%(\mathrm{w} / \mathrm{v})$ gave the heaviest weights of larvae, silk gland and male and female pupae of the mulberry silkworm B. mori L.. Also, Nagda ElSayed (1999) reported that the mixture of honey and black cumin seeds gave the heaviest weights of larvae, pupae and dry silk gland. Also Magda Abd El - Aziz,. (2002) found that larvae treated with some vegetable oils gave high efficiency on the mean weight of cocoon shell and number of deposited eggs/female at low concentration of $0.05 \%$.

Ngukue et al., (2007) found that the treatment of late age silkworm larvae with royal jelly elicits favourable response in improving the commercial qualities of silk fibre and can be used in sericulture for yield enhancement. Zah et al., (2011) used different sources of fat on four different silkworm hybrid strands, they observed an increase in the individual mass and silk quantity compared to the control. 
In conclusion the results of the present study proved the significant efficiency of the use of honey, oils and mixtures of them in improving the biometrics of Bombyx $m o r i \mathrm{~L}$. leading to increase of silk and egg production.

On contrast, application of of humic acid increased significantly plant fresh and dry weight, leaves number and leaves area of radish and common bean plants grown under polluted and unpolluted soils(Tables 2 and 3). The increments were 14.63 and $14.09 \%$ in plant fresh weight, 6.23 and $3.19 \%$ in plant dry weight, 17.15 and $19.49 \%$ in leaves number and 4.6 and $3.05 \%$ in leaves area compared to the control of radish plants in the first and the second seasons respectively. On the other hand the corresponding values for common bean plants were 11.72 and $10.72 \%$ in plant fresh weight, 9.73 and $7.98 \%$ in plant dry weight, 20.59 and $18.55 \%$ in leaves number and 39.69 and 33.82 in leaves area in the first and the second seasons respectively, as compared to control. Studies on the positive effects of humic substances on plant growth have resulted in improved effects on growth independent of nutrition ( Dursun et al,2002). The stimulating effects of humic substances on plants growth have been reported, i.e., increase dry weight of shoot, root growth, plant height and macronutrient uptake in

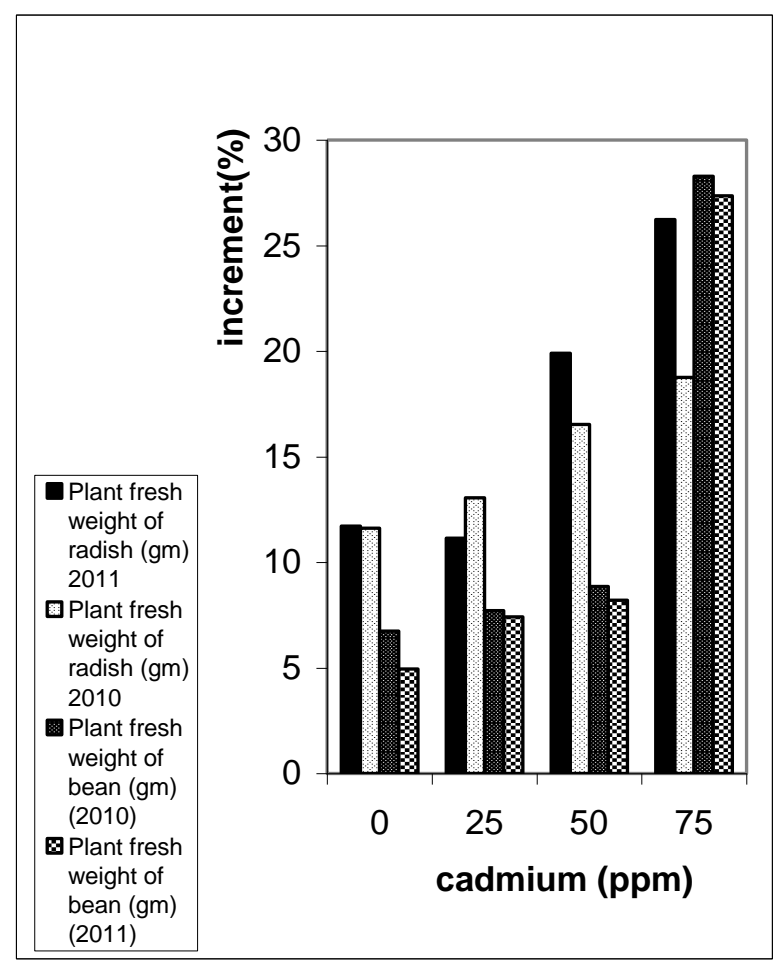

Figure 1. Interaction effect of cadmium and humic acid on fresh weight of bean radish during 2010 and 2011 seasons oat plants (Rosa et al., 2004); enhance phosphorus uptake and dry matter production in corn (Andrade et al., 2004); stimulate growth and leaf $\mathrm{N}$ and chlorophyll content in wild olive (Murillo et al., 2005) and increased root and leaf dry weight, root diameter, root length as well as leaf fresh weight and leaf crude proteins in forage turnip (Albayrak and Camas, 2005). humic acid can stimulate shoot and root growth dry and fresh weight and improved resistance to environmental stress in plants(Hartwigsen and Evans 2000), Because of its bonding ability to $\mathrm{Cd}$ and preventing its absorption.

The interaction between Cd levels and humic acid treatments on plant fresh weight, leaves number and leaves area were found significant in both experimental seasonsin radish and bean plants (Figures 1 -4). At 75 ppm of Cd treatment, plant fresh weight, leaves number and leaves area increased by 26.22 and $18.76,35.55$ and 36.73, 9.34 and 7.4 in radish plants. A similar effect was reflected on plant fresh weight, leaves number and leaves area and the increments were 28.29 and 27.35, 33.07 and $29.19,122.03$ and 113.53 in common bean in the first and second seasons respectively, compared to control.

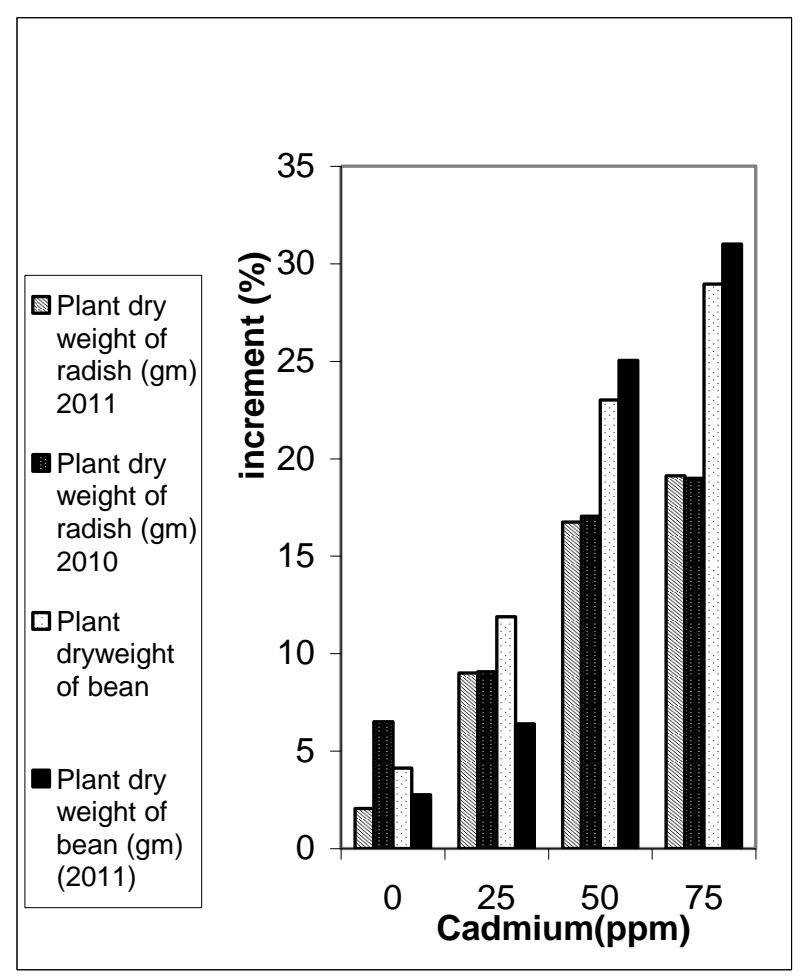

Figure 2. Interaction effect of cadmium and humic acid on dry weight of bean and radish during 2010 and 2011 seasons 


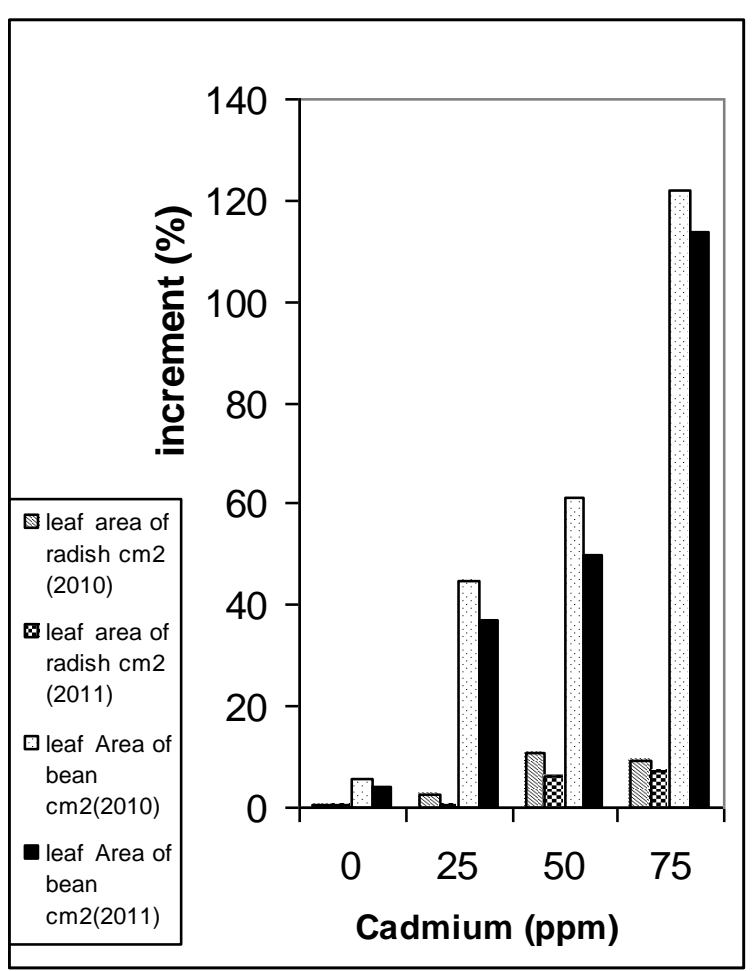

Figure 3. Interaction effect of cadmium and humic acid on leaf area of bean and radish during 2010 and 2011 seasons

\section{Yield and its component}

In radish plants, Root fresh weight, Root length and root thickness showed a significant declines under $\mathrm{Cd}$ stress by 31.85 and 31.96, 17.98 and 17.72and 28.53 and 27.19 at $75 \mathrm{ppm} \mathrm{Cd}$ as compared to control in the first and second seasons respectively (Table 4). Also Yield of green pods plant ${ }^{-1}$ and average number of green pods plant ${ }^{-1}$ were negatively affected by $\mathrm{Cd}$ treatments (Table 5). The depressions were severely at the rates of 50 and $75 \mathrm{ppm} \mathrm{Cd}$. The reductions of green pod yield plant $^{-1}$, the average number of pods per plant, yield of dry pods plant ${ }^{-1}$ and yield of dry seeds plant ${ }^{-1}$ were recorded by 66.7 and $66.8 \%, 67.8$ and $65.4 \%, 70.5$ and 70.7 and 35.5 and 33.24 as compared to control in the first and second seasons respectively, at $75 \mathrm{ppm} \mathrm{Cd(}$ Table 5). These results are in agreement with those obtained by El-Ghinbihi (2000) on common bean who found that number of pods per plant was significantly decreased with increasing Cd level in the soil. AbdulGhani (2010) on mung bean found that cadmium at the concentration of $12 \mathrm{ppm}$ decreased number of pods per plant, average of length of pod, pods fresh and dry weight per plant and number of seeds per plant of compared to control .

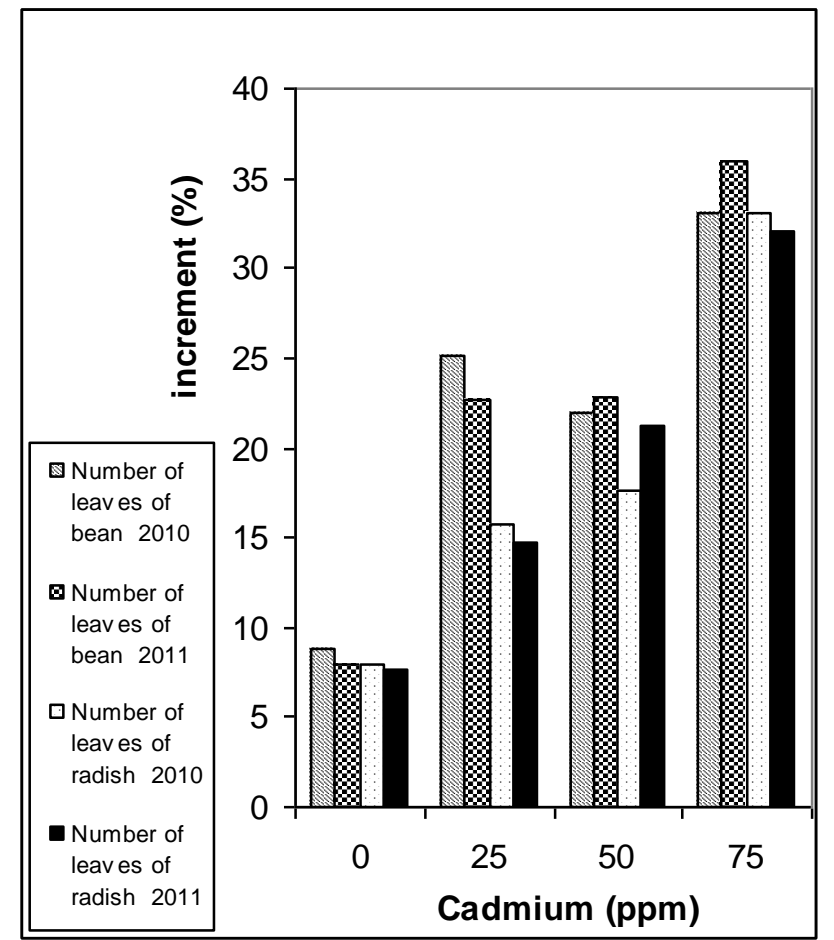

\section{Figure 4 .Interactian effect of cadmium and humic acid on number of leaves of bean and radish plants during 2010 and 2011 seasons}

Addition of humic acid significantly increased yield components of radish and common bean plants in both seasons (Tables 4and 5). Treating polluted soils with humic acid increased root fresh weight and seed yield pot $^{-1}$ of radish plants by 16.02 and $18.84 \%$ and 5.27 and $2.19 \%$ on the other hand in bean plants the number and yield of green pods plant ${ }^{-1}$ increased by $28.93,32.9 \%$ and $32.46,25.72 \%$, whereas yield of dry pods and dry seeds plant $^{-1}$ increased by $39.08,33.39 \%$ and 31.67 , $26.05 \%$ over the control treatment in the first and second seasons respectively.

The interaction between $\mathrm{Cd}$ levels and humic acid treatments were found significant in both seasons (Figures 5-10). The increments at $75 \mathrm{ppm}$ cadmium and $150 \mathrm{mg} \mathrm{kg}^{-1}$ soil humic acid on yield of dry seeds pot $^{-1}$ in radish plants were 6.01 and $3.55 \%$ at first and second seasons respectively compared to control .On the other hand the increments in bean plant were $63.5,78.4 \%$ and 83.71, 56.24\% and $128.5,121.11 \%$ and 144.66, $136.91 \%$ for number of green pods plant ${ }^{-1}$, yield of green pods plant ${ }^{-1}$, yield of dry pods plant ${ }^{1}$ and yield of dry seeds plant ${ }^{-1}$ at first and second seasons respectively compared to control .

The positive influences of humic acid on plant growth, which seem to be due to hormone-like activities 
of the humic acids through their involvement in cell respiration, photosynthesis, oxidative phosphorlation, protein synthesis, and various enzymatic reactions (Muscolo et al., 1999).

\section{$\mathrm{N}, \mathbf{P}$ and $K$ contents}

Nitrogen contents in common bean and radish plants as affected by $\mathrm{Cd}$ levels are shown in Tables (6 and 7). Increasing $\mathrm{Cd}$ levels in the soil significantly decreased N,P and $\mathrm{k}$ contents of leaves of common bean and radish in both seasons and the reduction of these elements was higher in bean than radish plants. At the highest $\mathrm{Cd}$ level (75 ppm) N,P and $\mathrm{k}$ contents were decreased in radish leaves by 13.03 and $12.5 \%, 16.67$ and $14.63 \%$ and 10.54 and $11.17 \%$ of the control in the first and second seasons respectively meanwhile in bean plants cadmium reduced nitrogen, phosphorus and potassium uptake by 35.39 and $36.08 \%, 45.45$ and $35.56 \%$ and 63.38 and 54.55 of the control in the first and second seasons respectively. These results seemed to be in agreement with those reported by Barcelo and poschenriederi (1990) who found that Cadmium reduced the uptake of nitrogen, phosphorus and potassium due to its effect on plant water relationships causing a direct reduction in the absorption surface by inhibiting the formation of root hairs and reduce membrane permeability.

The main effects of humic acid treatments reflected significant differences in N, P and K contents of leaves of common bean and radish plants in both seasons (Tables 6and 7).

Table 4. Root fresh weight $(\mathrm{g})$, Tap root length $(\mathrm{cm})$ and Tap root thickness $(\mathrm{cm})$ of radish plants as different levels of cadmium and humic acid during the two growing seasons of 2010 and 2011

\begin{tabular}{|c|c|c|c|c|c|c|c|c|c|}
\hline & & \multicolumn{2}{|c|}{$\begin{array}{l}\text { Root fresh weight } \\
\text { (gm) }\end{array}$} & \multicolumn{2}{|c|}{$\begin{array}{c}\text { Tap Root length } \\
(\mathrm{cm})\end{array}$} & \multicolumn{2}{|c|}{$\begin{array}{l}\text { Tap root thickness } \\
(\mathrm{cm})\end{array}$} & \multicolumn{2}{|c|}{$\begin{array}{c}\text { seed yield of radish } \\
\text { /pot }\end{array}$} \\
\hline & & $\begin{array}{l}2010 \\
\text { season }\end{array}$ & $\begin{array}{c}2011 \\
\text { season }\end{array}$ & $\begin{array}{c}2010 \\
\text { season }\end{array}$ & $\begin{array}{c}2011 \\
\text { season }\end{array}$ & $\begin{array}{c}2010 \\
\text { season }\end{array}$ & $\begin{array}{c}2011 \\
\text { season }\end{array}$ & $\begin{array}{c}2010 \\
\text { season }\end{array}$ & $\begin{array}{c}2011 \\
\text { season }\end{array}$ \\
\hline \multirow{4}{*}{ 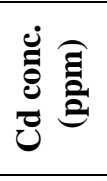 } & 0 & $76.66 \mathrm{~A}$ & $74.97 \mathrm{~A}$ & $12.40 \mathrm{~A}$ & $12.07 \mathrm{~A}$ & $6.80 \mathrm{~A}$ & $6.40 \mathrm{~A}$ & $44.53 \mathrm{~A}$ & $43.34 \mathrm{~A}$ \\
\hline & 25 & $56.73 \mathrm{~B}$ & $59.65 \mathrm{~B}$ & $11.12 \mathrm{~B}$ & $10.92 \mathrm{~B}$ & $6.40 \mathrm{~B}$ & $6.00 \mathrm{~A}$ & $41.67 \mathrm{~B}$ & $40.17 \mathrm{~B}$ \\
\hline & 50 & $56.60 \mathrm{~B}$ & $55.97 \mathrm{~B}$ & $10.60 \mathrm{C}$ & $10.42 \mathrm{~B}$ & $5.39 \mathrm{C}$ & $5.00 \mathrm{~B}$ & $37.33 \mathrm{C}$ & $35.85 \mathrm{C}$ \\
\hline & 75 & $52.24 \mathrm{C}$ & $51.01 \mathrm{C}$ & $10.17 \mathrm{D}$ & $9.93 \mathrm{C}$ & $4.86 \mathrm{D}$ & $4.66 \mathrm{~B}$ & $34.44 \mathrm{D}$ & $34.10 \mathrm{C}$ \\
\hline \multirow{3}{*}{ 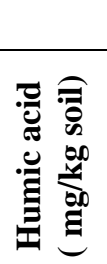 } & & 31.85 & 31.96 & 17.98 & 17.72 & 28.53 & 27.19 & & \\
\hline & 0 & $56.07 \mathrm{~B}$ & $55.2 \mathrm{~B}$ & $10.77 \mathrm{~B}$ & $10.56 \mathrm{~B}$ & $5.56 \mathrm{~B}$ & $5.23 \mathrm{~B}$ & $38.48 \mathrm{~B}$ & $37.95 \quad \mathrm{~B}$ \\
\hline & 150 & $65.05 \mathrm{~A}$ & $65.6 \mathrm{~A}$ & $11.37 \mathrm{~A}$ & $11.11 \mathrm{~A}$ & $6.17 \mathrm{~A}$ & $5.8 \mathrm{~A}$ & $40.51 \mathrm{~A}$ & $38.78 \quad \mathrm{~B}$ \\
\hline
\end{tabular}

*Values having a common alphabetical letter (s), do not significantly differ, using the revised L.S.D. test at P=0.05

Table 5. Effect of soil $\mathrm{Cd}$ pollution and humic acid treatment on yield and its component of common bean cv. Giza3 during 2010 and 2011 seasons

\begin{tabular}{|c|c|c|c|c|c|c|c|c|c|}
\hline & & \multicolumn{2}{|c|}{$\begin{array}{c}\text { Number of green } \\
\text { pods/plant }\end{array}$} & \multicolumn{2}{|c|}{$\begin{array}{c}\text { yield of green } \\
\text { pods/plant (gm) }\end{array}$} & \multicolumn{2}{|c|}{$\begin{array}{c}\text { yield of dry } \\
\text { pods/plant (gm) }\end{array}$} & \multicolumn{2}{|c|}{$\begin{array}{c}\text { yield of dry } \\
\text { seeds/plant (gm) }\end{array}$} \\
\hline & & $\begin{array}{c}2010 \\
\text { season }\end{array}$ & $\begin{array}{c}2011 \\
\text { season } \\
\end{array}$ & $\begin{array}{c}2010 \\
\text { season }\end{array}$ & $\begin{array}{c}2011 \\
\text { season }\end{array}$ & $\begin{array}{c}2010 \\
\text { season }\end{array}$ & $\begin{array}{c}2011 \\
\text { season }\end{array}$ & $\begin{array}{c}2010 \\
\text { season }\end{array}$ & $\begin{array}{c}2011 \\
\text { season }\end{array}$ \\
\hline \multirow{4}{*}{ 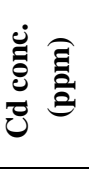 } & 0 & $15.00 \mathrm{~A}$ & $14.77 \mathrm{~A}$ & $61.20 \mathrm{~A}$ & $60.09 \mathrm{~A}$ & $11.13 \mathrm{~A}$ & $10.92 \mathrm{~A}$ & $8.95 \mathrm{~A}$ & $8.79 \mathrm{~A}$ \\
\hline & 25 & $8.67 \mathrm{~B}$ & $8.83 \mathrm{~B}$ & $41.87 \mathrm{~B}$ & $40.06 \mathrm{~B}$ & $7.85 \mathrm{~B}$ & $7.54 \mathrm{~B}$ & $6.72 \mathrm{~B}$ & $6.44 \mathrm{~B}$ \\
\hline & 50 & $5.83 \mathrm{C}$ & $6.17 \mathrm{C}$ & $29.67 \mathrm{C}$ & $27.92 \mathrm{C}$ & $4.90 \mathrm{C}$ & $4.60 \mathrm{C}$ & $4.00 \mathrm{C}$ & $3.76 \mathrm{C}$ \\
\hline & 75 & $4.83 \mathrm{D}$ & $5.11 \mathrm{D}$ & $20.38 \mathrm{D}$ & $19.93 \mathrm{D}$ & $3.28 \mathrm{D}$ & $3.20 \mathrm{D}$ & $2.58 \mathrm{D}$ & $2.51 \mathrm{D}$ \\
\hline \multirow{2}{*}{ 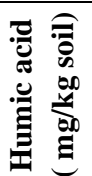 } & 0 & $7.5 \mathrm{~B}$ & $7.5 \mathrm{~B}$ & $32.93 \mathrm{~B}$ & $32.93 \mathrm{~B}$ & $5.68 \mathrm{~B}$ & $5.68 \mathrm{~B}$ & $4.80 \mathrm{~B}$ & $4.76 \mathrm{~B}$ \\
\hline & 150 & $9.67 \mathrm{~A}$ & $9.67 \mathrm{~A}$ & $43.62 \mathrm{~A}$ & $43.62 \mathrm{~A}$ & $7.9 \mathrm{~A}$ & $7.90 \mathrm{~A}$ & $6.32 \mathrm{~A}$ & $6.32 \mathrm{~A}$ \\
\hline
\end{tabular}




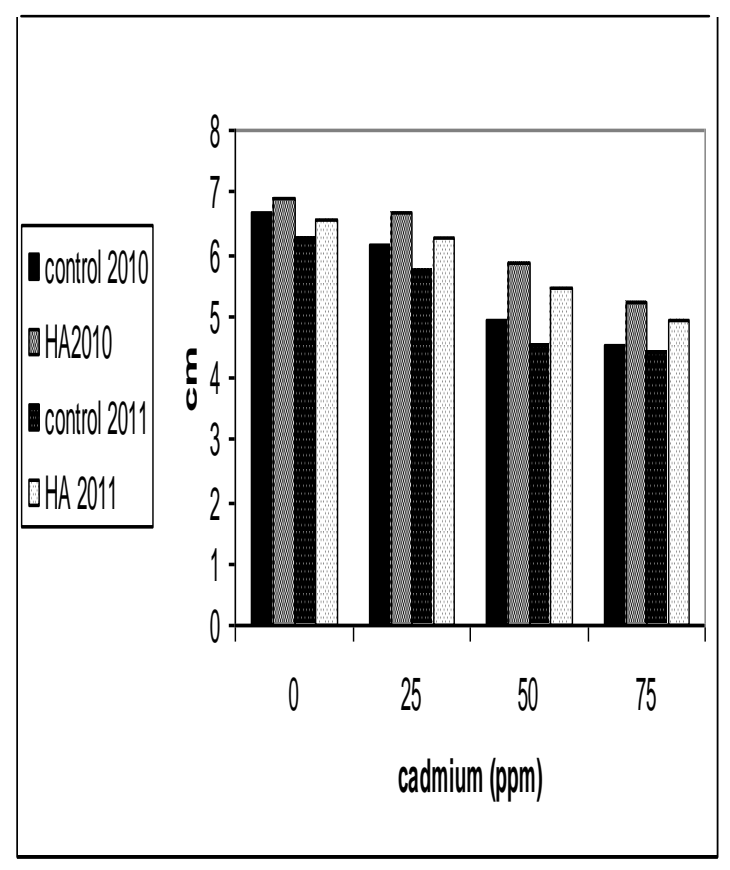

Figure 5. Tap root thickness $(\mathrm{cm})$ of radish plants as different levels of cadmium and humic acid during the two growing seasons of 2010 and 2011.

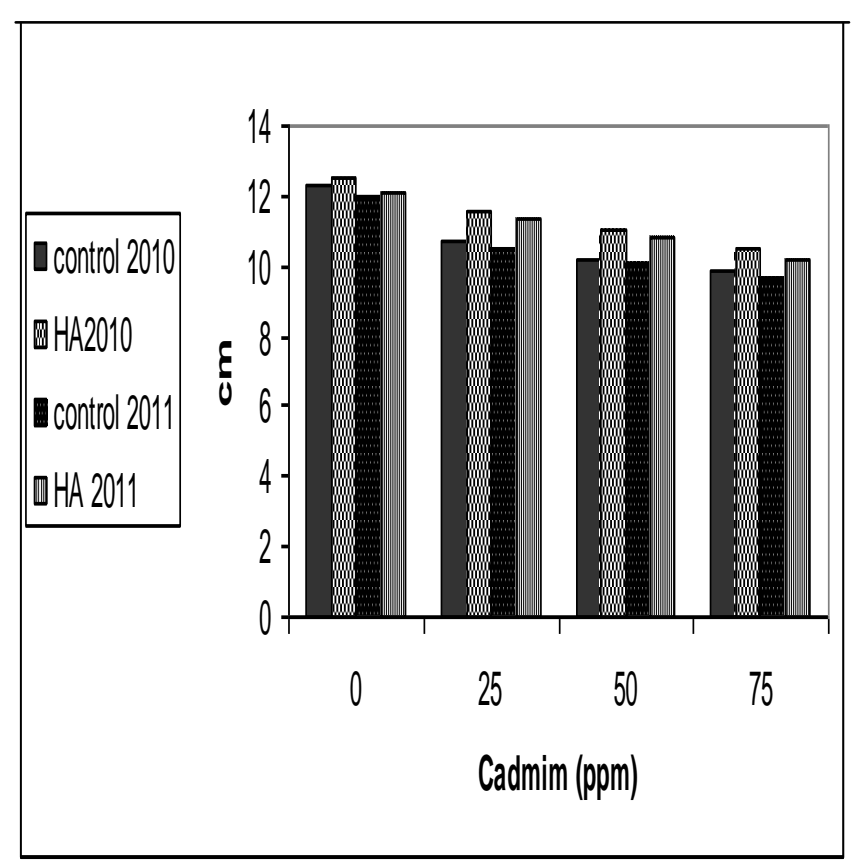

Figure 6. Tap root length $(\mathrm{cm})$ of radish plants as different levels of cadmium and humic acid during the two growing seasons of 2010 and 2011.

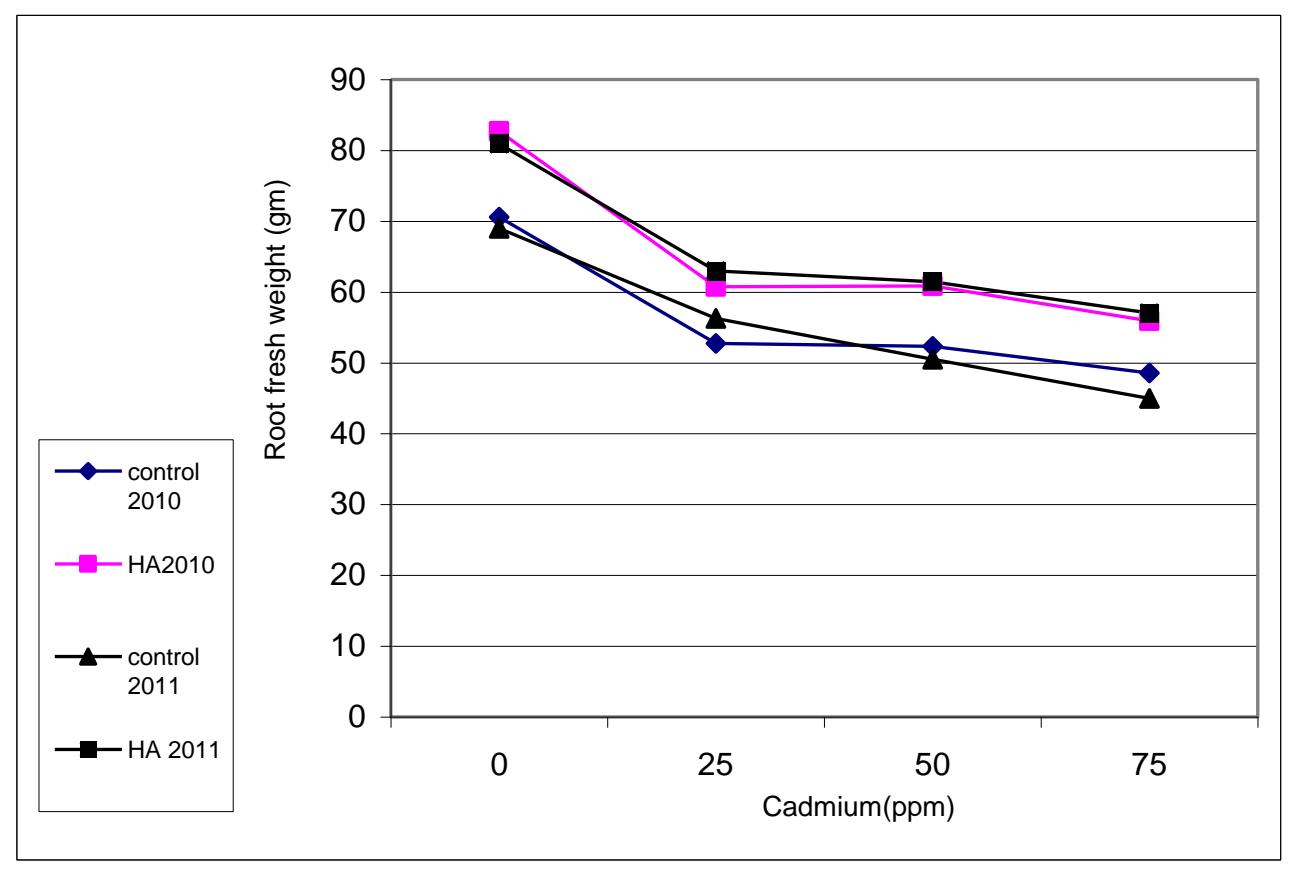

Figure 7. Interaction effect of cadmium and humic acid on Root fresh weight (g) of radish plants as different levels of cadmium and humic acid during the two growing seasons of 2010 and 2011 


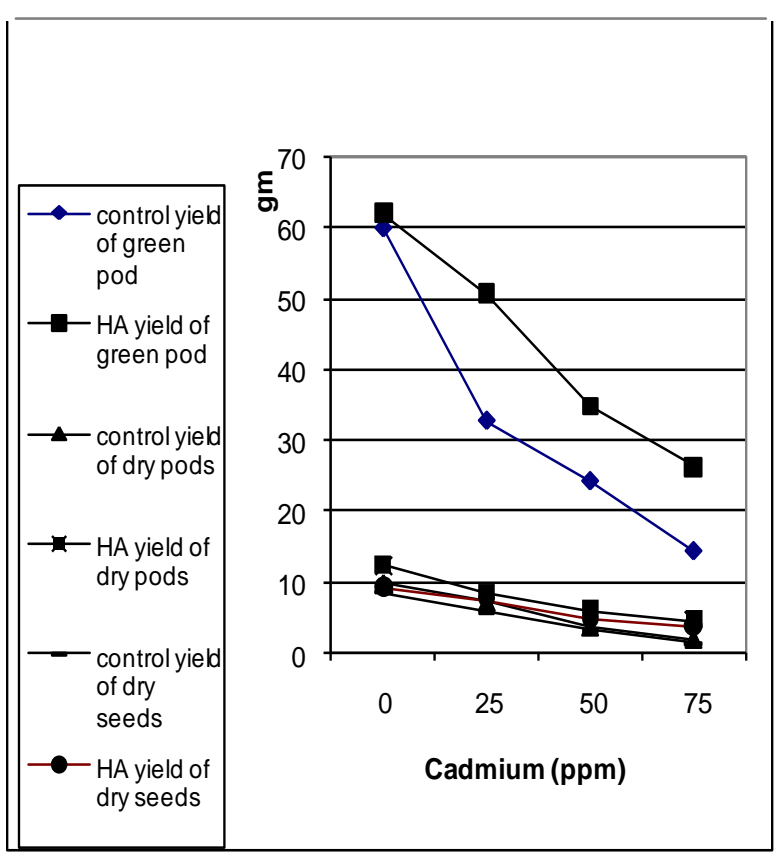

Figure 8. Interaction effect of cadmium and humic acid on yield of bean during 2010 season

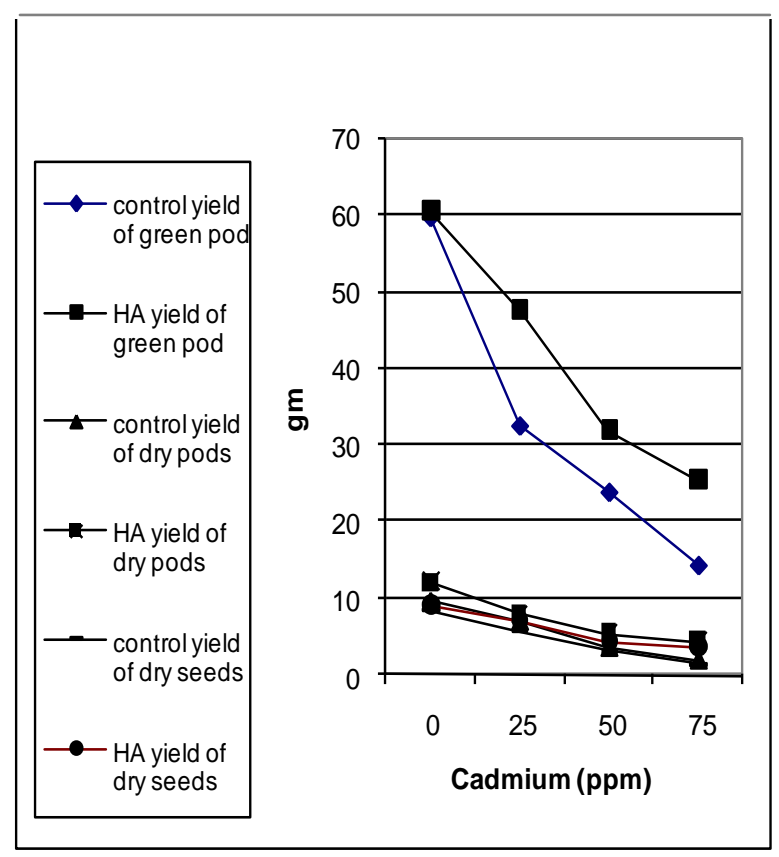

Figure 9. Interaction effect of cadmium and humic acid on yield of bean under different levels of cadmium during second season

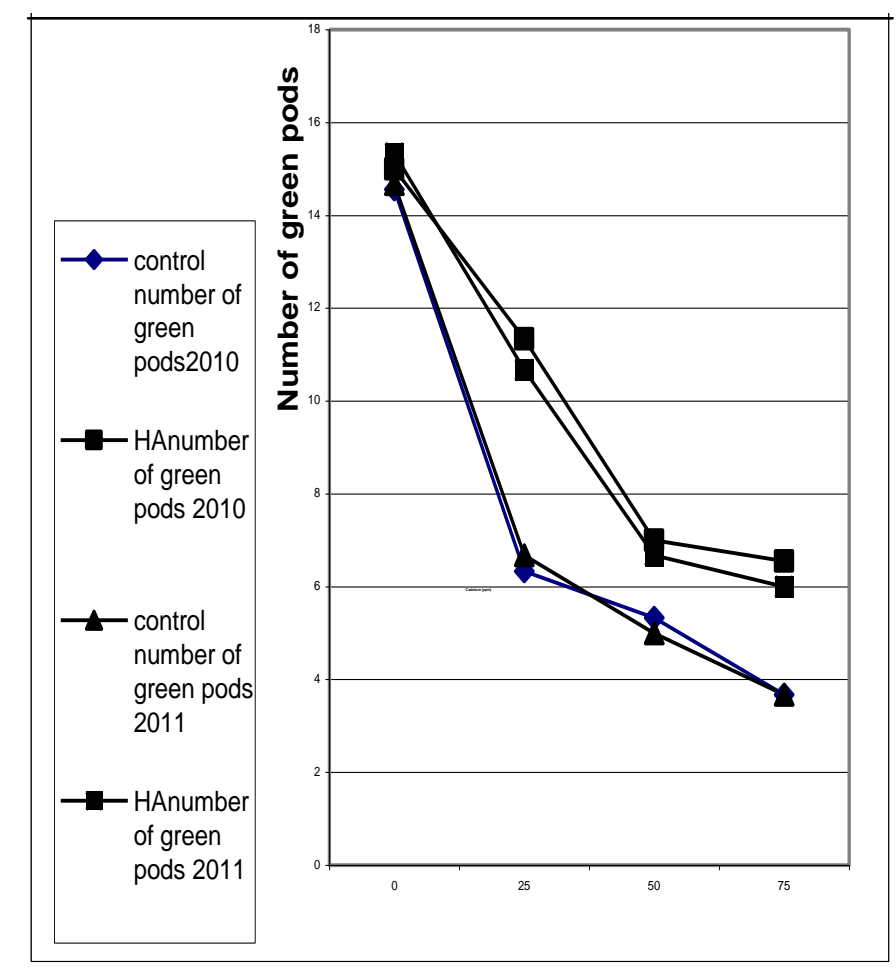

Figure 10. Interaction effect of cadmium and humic acid on number of green pods of bean during 2010 and 2011seasons 
Table 6. N,P and $K \%$ contents of radish plants as affected by different levels of cadmium and humic acid during the two growing seasons of 2010 and 2011

\begin{tabular}{|c|c|c|c|c|c|c|c|}
\hline & & \multirow{2}{*}{\multicolumn{2}{|c|}{$\begin{array}{c}\mathrm{N \%} \\
\text { in radish leaves }\end{array}$}} & \multirow{2}{*}{\multicolumn{2}{|c|}{$\begin{array}{c}\mathbf{P} \% \\
\text { in radish leaves } \\
\end{array}$}} & \multirow{2}{*}{\multicolumn{2}{|c|}{$\begin{array}{c}\mathbf{k} \% \\
\text { in radish leaves }\end{array}$}} \\
\hline & & & & & & & \\
\hline & & $\begin{array}{c}2010 \\
\text { season }\end{array}$ & $\begin{array}{c}2011 \\
\text { season }\end{array}$ & $\begin{array}{c}2010 \\
\text { season }\end{array}$ & $\begin{array}{c}2011 \\
\text { season }\end{array}$ & $\begin{array}{c}2010 \\
\text { season } \\
\end{array}$ & $\begin{array}{c}2011 \\
\text { season }\end{array}$ \\
\hline \multirow{4}{*}{ 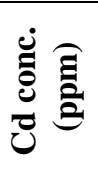 } & 0 & $3.99 \mathrm{~A}$ & $3.92 \mathrm{~A}$ & $0.42 \mathrm{~A}$ & $0.41 \mathrm{~A}$ & $4.08 \mathrm{~A}$ & $4.03 \mathrm{~A}$ \\
\hline & 25 & $3.80 \mathrm{~B}$ & $3.74 \mathrm{~B}$ & $0.38 \mathrm{~B}$ & $0.37 \mathrm{~B}$ & $3.88 \mathrm{AB}$ & $3.79 \mathrm{AB}$ \\
\hline & 50 & $3.70 \mathrm{C}$ & $3.63 \mathrm{C}$ & $0.37 \mathrm{C}$ & $0.37 \mathrm{C}$ & $3.80 \mathrm{~B}$ & $3.72 \mathrm{~B}$ \\
\hline & 75 & $3.47 \mathrm{D}$ & $3.43 \mathrm{D}$ & $0.35 \mathrm{D}$ & $0.35 \mathrm{D}$ & $3.65 \mathrm{~B}$ & $3.58 \mathrm{~B}$ \\
\hline \multirow{2}{*}{ 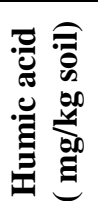 } & 0 & $3.67 \mathrm{~B}$ & $3.62 \mathrm{~B}$ & $0.37 \mathrm{~B}$ & $0.36 \mathrm{~B}$ & $3.80 \mathrm{~B}$ & $3.73 \mathrm{~B}$ \\
\hline & 150 & $3.81 \mathrm{~A}$ & $3.74 \mathrm{~A}$ & $0.39 \mathrm{~A}$ & $0.38 \mathrm{~A}$ & $3.90 \mathrm{~A}$ & $3.84 \mathrm{~A}$ \\
\hline
\end{tabular}

Table 7. N,P and $K \%$ contents of bean plants as affected by different levels of cadmium and humic acid during the two growing seasons of 2010 and 2011

\begin{tabular}{|c|c|c|c|c|c|c|c|}
\hline & & \multicolumn{2}{|c|}{ N\% } & \multicolumn{2}{|c|}{ P\% } & \multicolumn{2}{|c|}{$\mathrm{k} \%$} \\
\hline & & \multicolumn{2}{|c|}{ in common bean leaves } & \multicolumn{2}{|c|}{ in common bean leaves } & \multicolumn{2}{|c|}{ in common bean leaves } \\
\hline & & $\begin{array}{c}2010 \\
\text { season }\end{array}$ & $\begin{array}{c}2011 \\
\text { season }\end{array}$ & $\begin{array}{c}2010 \\
\text { season }\end{array}$ & $\begin{array}{c}2011 \\
\text { season }\end{array}$ & $\begin{array}{c}2010 \\
\text { season }\end{array}$ & $\begin{array}{c}2011 \\
\text { season }\end{array}$ \\
\hline \multirow{4}{*}{ 己ֶ } & 0 & $3.56 \mathrm{~A}$ & $3.52 \mathrm{~A}$ & $0.44 \mathrm{~A}$ & $0.45 \mathrm{~A}$ & $3.55 \mathrm{~A}$ & $3.30 \mathrm{~A}$ \\
\hline & 25 & $2.68 \mathrm{~B}$ & $2.71 \mathrm{~B}$ & $0.43 \mathrm{~A}$ & $0.42 \mathrm{~B}$ & $3.25 \mathrm{~A}$ & $3.00 \mathrm{~A}$ \\
\hline & 50 & $2.47 \mathrm{C}$ & $2.43 \mathrm{C}$ & $0.32 \mathrm{~B}$ & $0.33 \mathrm{C}$ & $2.65 \mathrm{~B}$ & $2.42 \mathrm{~B}$ \\
\hline & 75 & $2.3 \mathrm{D}$ & $2.25 \mathrm{D}$ & $0.24 \mathrm{C}$ & $0.29 \mathrm{D}$ & $1.3 \mathrm{C}$ & $1.50 \mathrm{C}$ \\
\hline \multirow{2}{*}{ 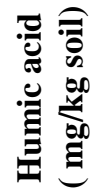 } & 0 & $2.63 \mathrm{~B}$ & $2.61 \mathrm{~B}$ & $0.325 \mathrm{~B}$ & $0.33 \mathrm{~B}$ & $2.55 \mathrm{~B}$ & $2.40 \mathrm{~B}$ \\
\hline & 150 & $2.9 \mathrm{~A}$ & $2.84 \mathrm{~A}$ & $0.39 \mathrm{~A}$ & $0.42 \mathrm{~A}$ & $2.82 \mathrm{~A}$ & $2.71 \mathrm{~A}$ \\
\hline
\end{tabular}

*Values having a common alphabetical letter (s), do not significantly differ, using the revised L.S.D. test at $\mathrm{P}=0.05$.

Humic acid treatment increased $\mathrm{N}, \mathrm{P}$ and $\mathrm{K}$ contents of leaves of radish plants by 3.81 and $3.31 \%, 5.41$ and $5.56 \%$ and 2.63 and $2.95 \%$ compared to the control in the first and second seasons, respectively. On the other hand the corresponding values for common bean plants were 10.27 and $8.81 \%, 20.0$ and $27.27 \%$ and 10.59 and $12.92 \%$ for $\mathrm{N}, \mathrm{P}$ and $\mathrm{K}$ in the first and second seasons, respectively.

The increased nutrient availability by HA would be attributed to the enhancement of microbial activity well as increased root growth which would have facilitated more efficient nutrient absorption (Mallikarjuna Rao et al. 1987).

\section{Chlorophyll content:}

Data for photosynthetic pigments in leaves of radish and common bean plants are presented in Tables $(8$ and
9) showed clearly that higher Cd concentration of 75 ppm significantly reduced chlorophyll a, chlorophyll b and total chlorophyll in radish plants by 19.64, 27.2 and $22.47 \%$ in the first season and by $22.74,28.15$ and $24.8 \%$, respectively in the second season compared to the control treatment. Meanwhile, at the same concentration the chlorophyll a, chlorophyll $\mathrm{b}$ and total chlorophyll were significantly decreased in common bean plants by $54.69,51.23$ and $52.94 \%$ in first season and by $55.28,49.28$ and $55.53 \%$, respectively, in the second season. Total chlorophyll in radish plants was less affected by $\mathrm{Cd}$ than common bean plants. Our results of decrease in chlorophyll content corroborated with the findings of Chandra et al (2011); and ElGhinbihi, (2000) who also found a decrease in chlorophyll content with heavy metal stress in Photosynthetic pigments have often been shown as one 
of the main sites of the toxic $\mathrm{Cd}$ and other heavy metal actions in many plant species such as cucumber, safflower, tomato and eggplant and common bean .Thus, the decrease in chlorophylls content appears to be one of the first visible bio-markers of Cd toxicity. The possible mechanism of toxicity on chlorophyll pigments were attributed to inhibiting the biosynthesis of the amino levulinic acid (ALA) a precursor of chlorophyll (Thomas and singh, 1996) and / or an enhancement of chlorophyll degradation occurs in Cd-treated plants due to increased chlorophyllase activity (Abdel-Basset et al., 1995).

The presence of humic acid counteracted the adverse effect of cadmium on chlorophyll contents which increased under such cadmium concentration (Tables 8and 9). The role of humic acid on increasing chlorophylls contents under normal or polluted soils with cadmium may be attributed to increasing nutrients uptake specially nitrogen and potassium which increased number of chloroplast per cell as well as photosynthetic efficiency. In addition, the application of HA inhibit indole acetic acid (IAA) oxidase, thereby hindering destruction of this plant growth hormone (Mato et al., 1972).

Concerning the interaction effects of humic acid and cadmium rates on chlorophylls contents of leaves of radish and bean plants (Figures 14-19), the results revealed that humic acid application significantly increased chlorophyll A and B contents of leaves under all cadmium level.

Table 8. Chlorophyll content of radish plants as affected by different levels of cadmium and humic acid during the two growing seasons of 2010 and 2011

\begin{tabular}{|c|c|c|c|c|c|c|c|}
\hline & & \multicolumn{2}{|c|}{$\begin{array}{c}\text { Chlorophyll A in radish } \\
\text { leaves }(\mu \mathrm{g} / 10 \mathrm{mg} \text { leaf dry wt.) }\end{array}$} & \multicolumn{2}{|c|}{$\begin{array}{c}\text { Chlorophyll B in radish leaves } \\
(\mu \mathrm{g} / 10 \mathrm{mg} \text { leaf dry wt })\end{array}$} & \multicolumn{2}{|c|}{$\begin{array}{l}\text { Total Chlorophyll in radish } \\
\text { leaves }(\mu \mathrm{g} / 10 \mathrm{mg} \text { leaf dry wt) }\end{array}$} \\
\hline & & $\begin{array}{c}2010 \\
\text { season } \\
\end{array}$ & $\begin{array}{c}2011 \\
\text { season }\end{array}$ & $\begin{array}{c}2010 \\
\text { season }\end{array}$ & $\begin{array}{c}2011 \\
\text { season }\end{array}$ & $\begin{array}{c}2010 \\
\text { season }\end{array}$ & $\begin{array}{c}2011 \\
\text { season }\end{array}$ \\
\hline \multirow{4}{*}{ 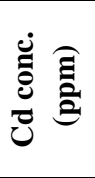 } & 0 & $64.50 \mathrm{~A}$ & $64.33 \mathrm{~A}$ & $38.67 \mathrm{~A}$ & $39.40 \mathrm{~A}$ & $103.17 \mathrm{~A}$ & $103.73 \mathrm{~A}$ \\
\hline & 25 & $62.00 \mathrm{~A}$ & $61.36 \mathrm{~A}$ & $35.17 \mathrm{~A}$ & $36.14 \mathrm{~A}$ & $97.17 \mathrm{~A}$ & $97.50 \mathrm{~A}$ \\
\hline & 50 & $58.16 \mathrm{~B}$ & $56.58 \mathrm{~B}$ & $31.27 \mathrm{~B}$ & $32.10 \mathrm{~B}$ & $89.44 \mathrm{~B}$ & $88.68 \mathrm{~B}$ \\
\hline & 75 & $51.83 \mathrm{D}$ & $49.70 \mathrm{C}$ & $28.15 \mathrm{C}$ & $28.31 \mathrm{~B}$ & $79.99 \mathrm{C}$ & $78.00 \mathrm{C}$ \\
\hline \multirow{2}{*}{ 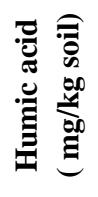 } & 0 & $57.108 \mathrm{~B}$ & $56.38 \mathrm{~B}$ & $32.47 \mathrm{~B}$ & $32.54 \mathrm{~B}$ & 89.57 B & $88.92 \mathrm{~A}$ \\
\hline & 150 & $61.14 \mathrm{~A}$ & $59.60 \mathrm{~A}$ & $34.16 \mathrm{~A}$ & $35.43 \mathrm{~A}$ & $95.30 \mathrm{~A}$ & $95.03 \mathrm{~B}$ \\
\hline
\end{tabular}

*Values having a common alphabetical letter (s), do not significantly differ, using the revised L.S.D. test at P=0.05.

Table 9. Chlorophyll content of bean plants as affected by different levels of cadmium and humic acid during the two growing seasons of 2010 and 2011

\begin{tabular}{|c|c|c|c|c|c|c|c|}
\hline & & \multicolumn{2}{|c|}{$\begin{array}{c}\text { Chlorophyll A in common } \\
\text { bean leaves }(\mu \mathrm{g} / 10 \mathrm{mg} \text { leaf } \\
\text { dry wt) }\end{array}$} & \multicolumn{2}{|c|}{$\begin{array}{c}\text { Chlorophyll B in common } \\
\text { bean leaves }(\mu \mathrm{g} / 10 \mathrm{mg} \text { leaf } \\
\text { dry wt) }\end{array}$} & \multicolumn{2}{|c|}{$\begin{array}{l}\text { Total Chlorophyll in } \\
\text { common bean leaves } \\
(\mu g / 10 m g \text { leaf dry wt) }\end{array}$} \\
\hline & & $\begin{array}{c}2010 \\
\text { season }\end{array}$ & $\begin{array}{c}2011 \\
\text { season }\end{array}$ & $\begin{array}{c}2010 \\
\text { season }\end{array}$ & $\begin{array}{c}2011 \\
\text { season }\end{array}$ & $\begin{array}{c}2010 \\
\text { season }\end{array}$ & $\begin{array}{c}2011 \\
\text { season }\end{array}$ \\
\hline \multirow{4}{*}{ 异 } & 0 & $58.73 \mathrm{~A}$ & $58.14 \mathrm{~A}$ & $28.83 \mathrm{~A}$ & $28.45 \mathrm{~A}$ & $87.57 \mathrm{~A}$ & $86.60 \mathrm{~A}$ \\
\hline & 25 & $48.26 \mathrm{~B}$ & $46.36 \mathrm{~B}$ & $22.58 \mathrm{~B}$ & $21.74 \mathrm{~B}$ & $70.85 \mathrm{~B}$ & $68.10 \mathrm{~B}$ \\
\hline & 50 & $32.91 \mathrm{C}$ & $30.94 \mathrm{C}$ & $18.58 \mathrm{C}$ & $17.77 \mathrm{C}$ & $51.50 \mathrm{C}$ & $48.71 \mathrm{C}$ \\
\hline & 75 & $26.61 \mathrm{D}$ & $26.00 \mathrm{D}$ & $14.60 \mathrm{D}$ & $14.43 \mathrm{D}$ & $41.21 \mathrm{D}$ & $40.43 \mathrm{D}$ \\
\hline \multirow{2}{*}{ 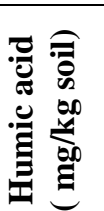 } & 0 & $37.41 \mathrm{~A}$ & $37.02 \mathrm{~B}$ & $18.94 \mathrm{~B}$ & $18.78 \mathrm{~B}$ & $56.35 \mathrm{~B}$ & $55.80 \mathrm{~B}$ \\
\hline & 150 & $45.86 \mathrm{~B}$ & $43.70 \mathrm{~A}$ & $23.36 \mathrm{~A}$ & $22.42 \mathrm{~A}$ & $69.22 \mathrm{~A}$ & $66.12 \mathrm{~A}$ \\
\hline
\end{tabular}




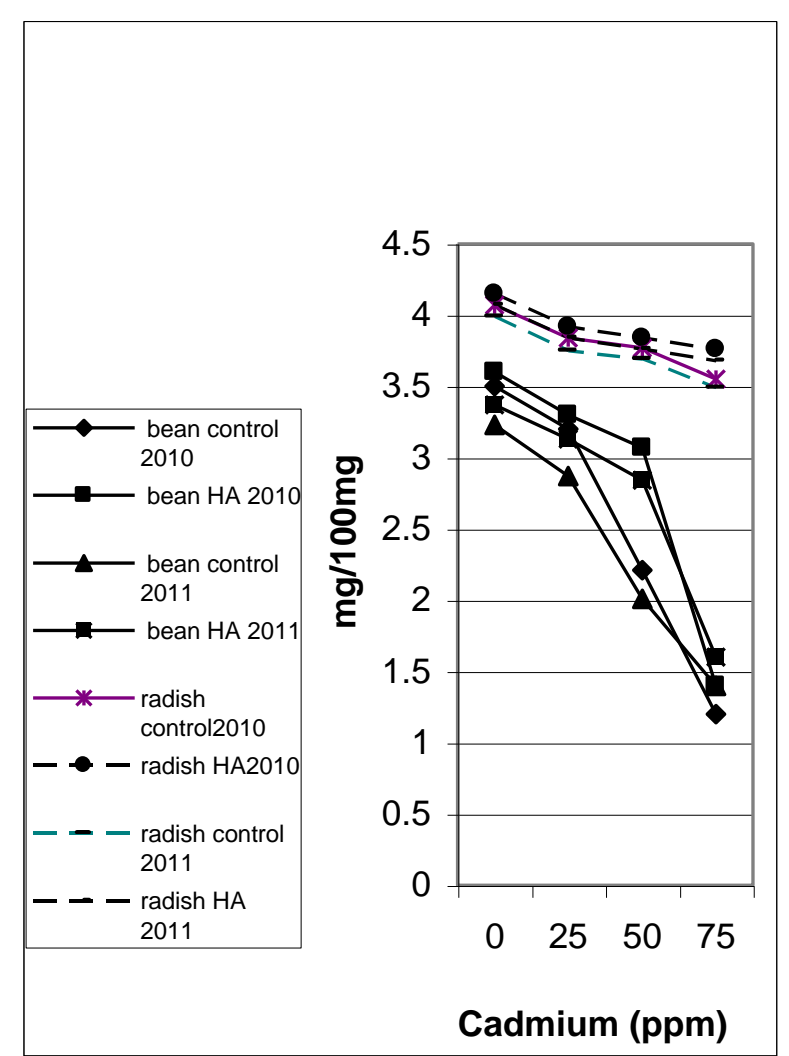

Figure 11. Interaction effect of cadmium and hurric acid on potassum in bean and radish leaves during 2010 and 2011 seasons

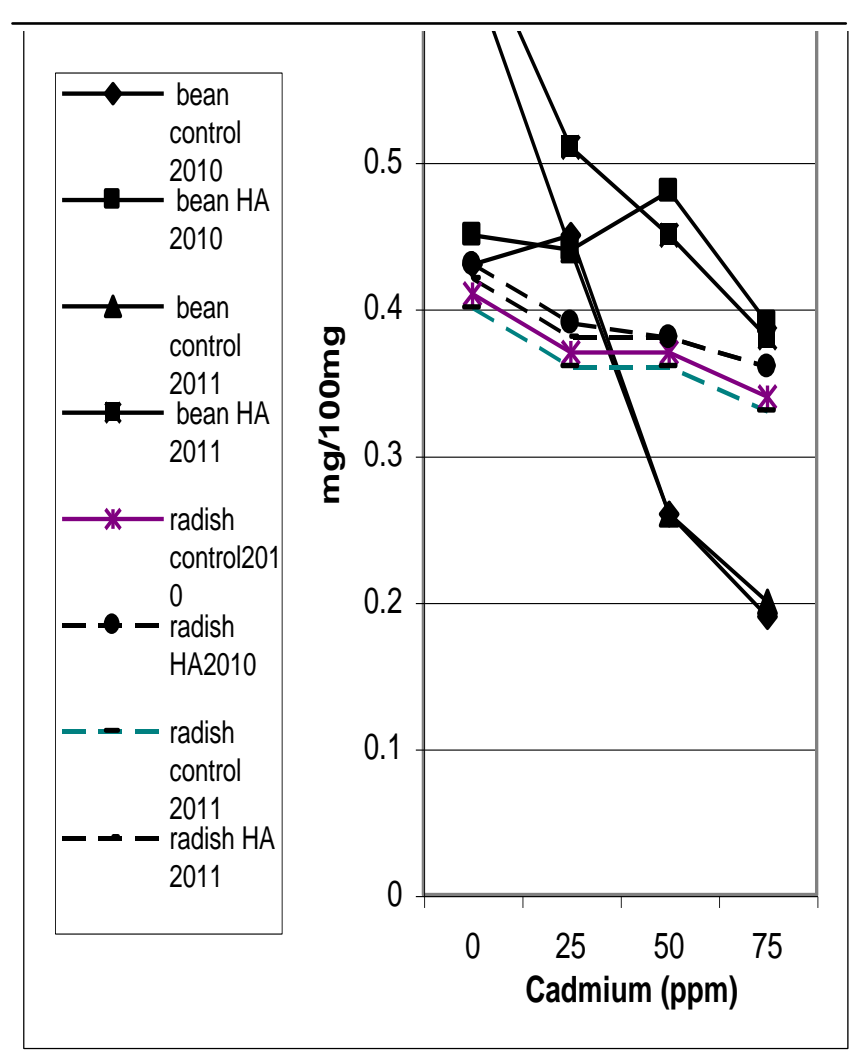

Figure 12. Interaction effect of cadmium and humic acidon phosphorus in bean and radish leaves during 2010 and 2011 seasons

seasons

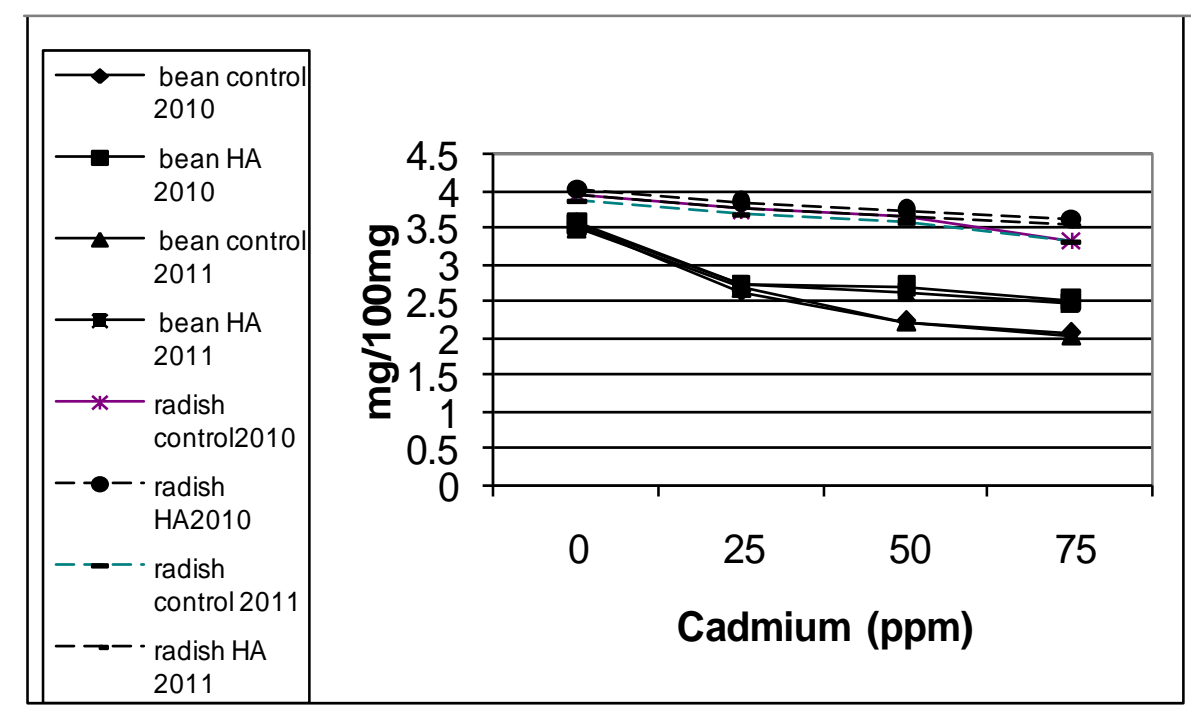

Figure 13. Interaction effect of cadmium and humic acid on nitrogen in bean and radish leaves during 2010 and 2011 seasons 


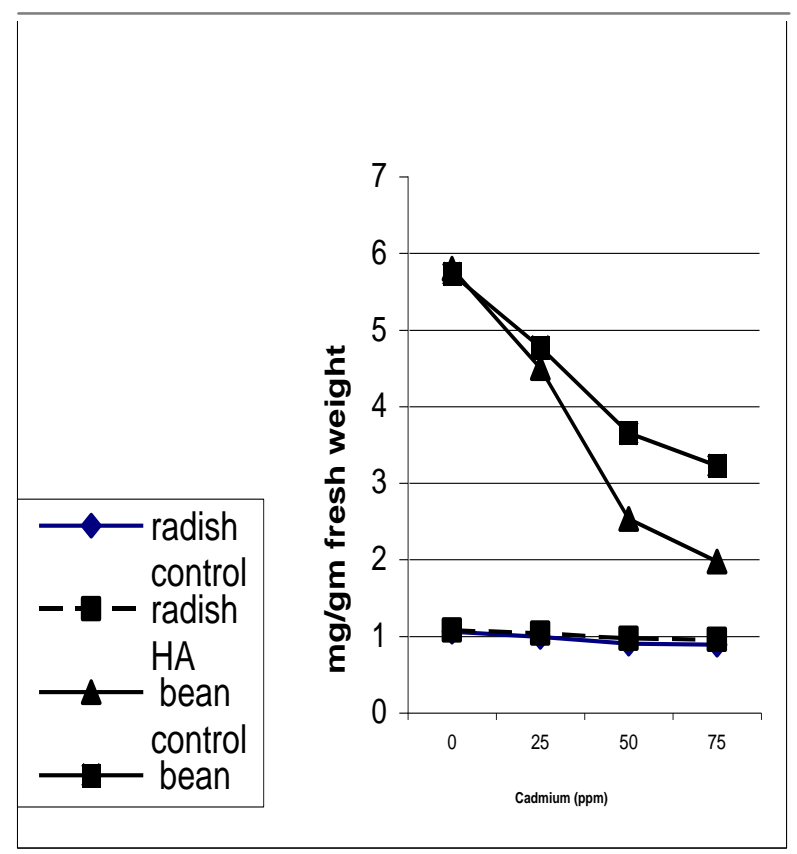

Figure 14. Effect of humic acid on chlorophyll a In bean and radish leaves under different levels of cadmium season 1

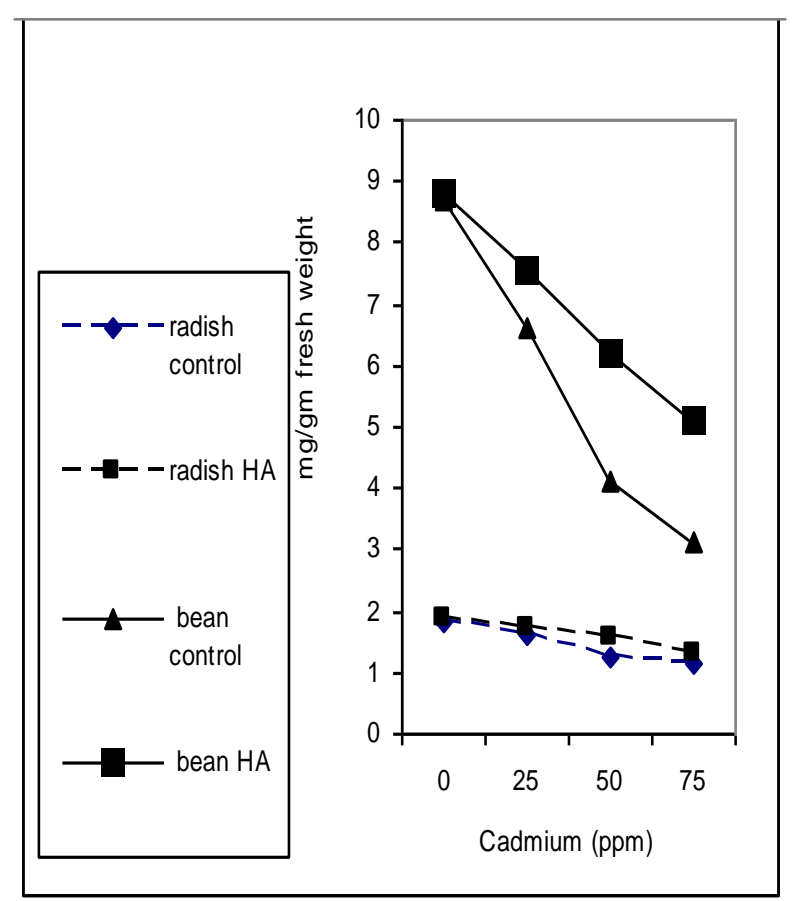

Figure 16. Interaction effect of cadmium and humic acid on total chlorophyll In bean and radish leaves during 2010 and 2011 seasons

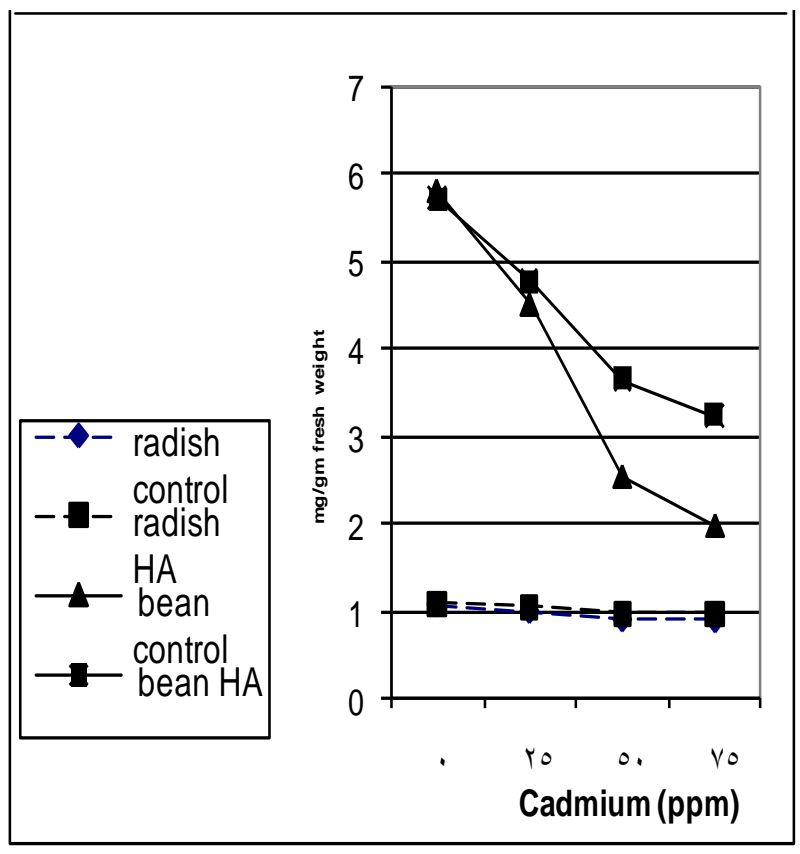

Figure 15. Interaction effect of cadmium and humic acidon chlorophy $U$ a in bean and radish leaves during 2010 and 2011 seasons

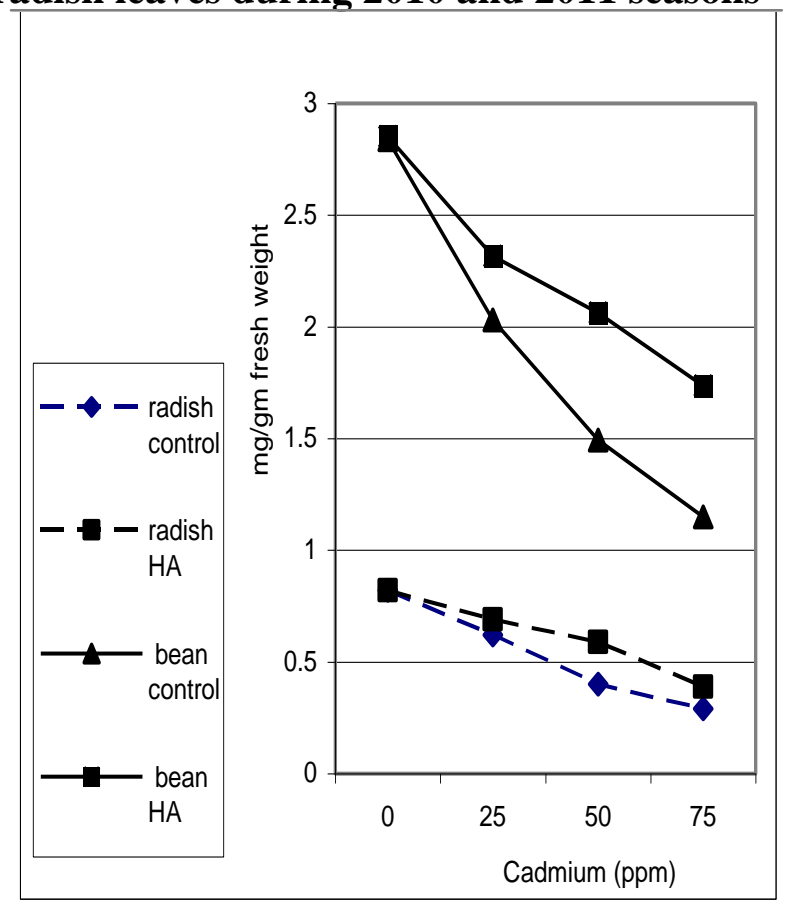

Figure 17. Interaction effect of cadmium and humic acid on chlorophyll $b$ In bean and radish leaves during 2010 and 2011 seasons 


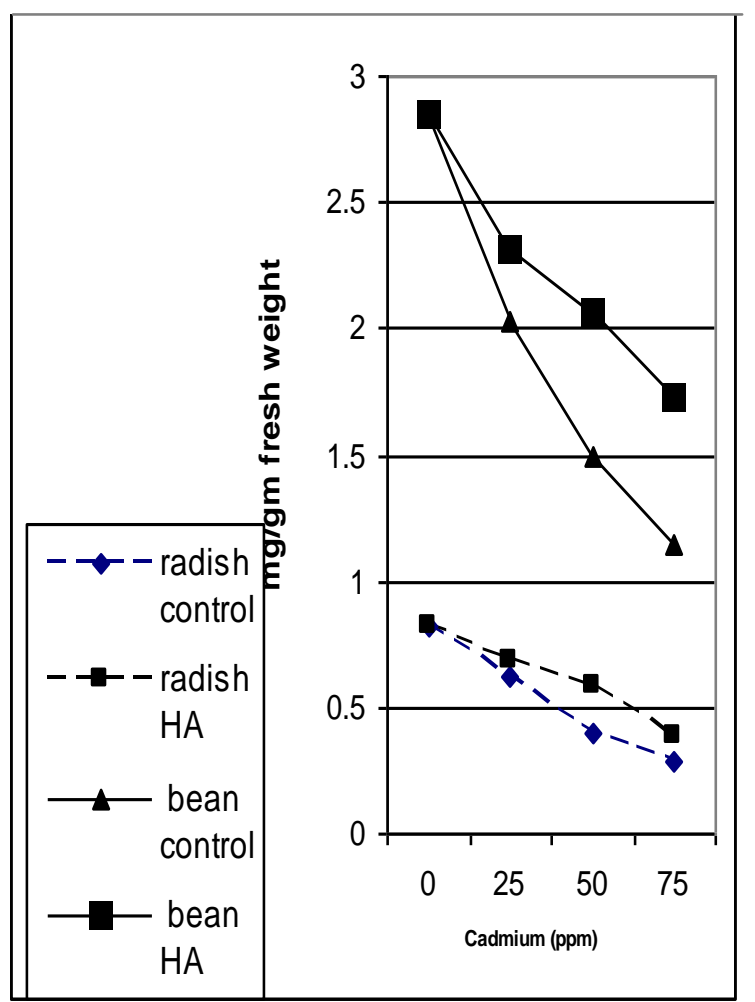

Figure 18. Interaction effect of cadmium and humic acidon chlorophyll $b$ in bean and radish leaves during 2010 and 2011 seasons

Leaf chlorophyll contents were positively increased by humic acid application under different levels of cadmium application on both seasons as compared to control plants. Karakurt et al. (2009) also supported these findings by reporting higher chlorophyll contents in peppers in response to humic acid application.

\section{Cadmium content}

Data presented in Table (10 and 11) indicated that increasing cadmium concentration in the soil up to 75 $\mathrm{mg} \mathrm{kg}^{-1}$ soil significantly increased the concentration of cadmium in plant tissue. A significant higher cadmium concentration in different plant parts observed at $75 \mathrm{ppm}$ compared to the $\mathrm{Cd}-50$ or $25 \mathrm{ppm}$ treatments. At the highest level of $\mathrm{Cd}$ application (75 ppm), cadmium content in roots, leaves and seeds of radish plants were 844.18 and 835.3, 212.33 and 213.31, 103.0 and $98.41 \mu \mathrm{g} / \mathrm{g}$ dry weight in the first and second seasons respectively, meanwhile in bean plants cadmium contents were 508.23 and 482.02, 146.3 and 144.91, 24.85 and $23.36 \mu \mathrm{g} / \mathrm{g}$ dry weight in roots, leaves and seeds in the first and second seasons respectively, data also showed that the concentration of $\mathrm{Cd}$ in roots of radish and bean plants were higher than those of the leaves or seeds. It is clear from the data that most of $\mathrm{Cd}$

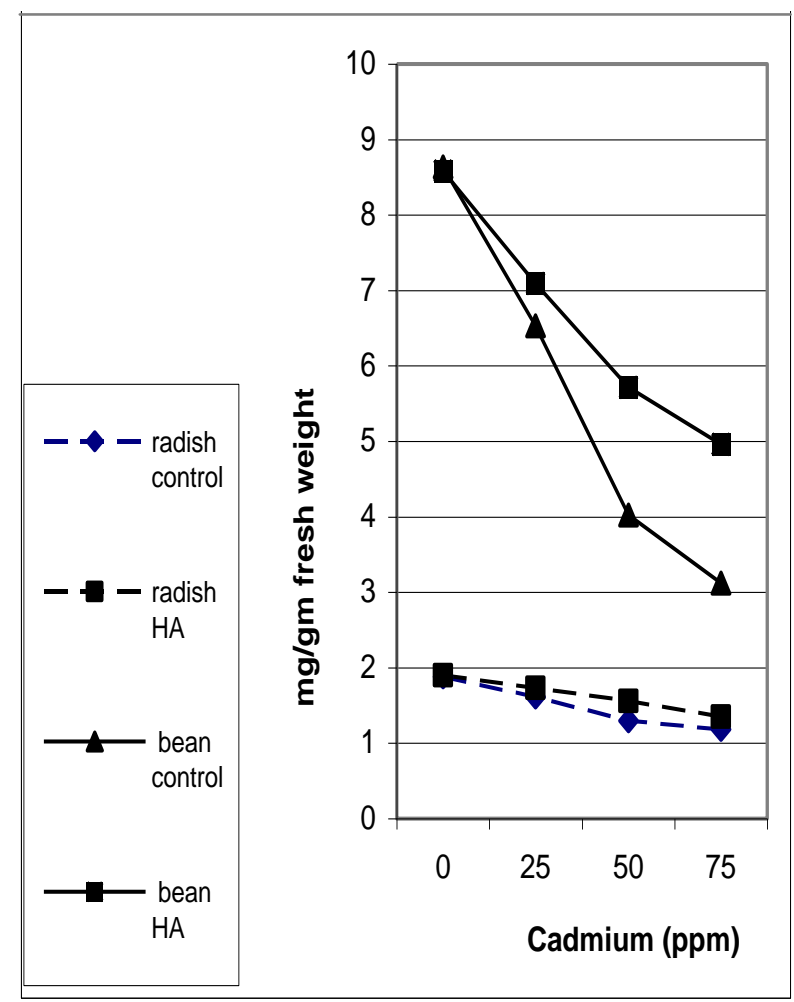

Figure 19. Inleraction effect of cadmium and humic acidon total chlorophyll In bean and radish during 2010 and 2011 seasons

taken up by radish and bean plants were retained in the roots and consequently less amount of $\mathrm{Cd}$ was translocated to shoots, indicating the ability of roots to accumulate high amounts of $\mathrm{Cd}$.

The precise cause of the these large differences in $\mathrm{Cd}$ concentration between roots and shoots has not been established, but several workers have suggested that the accumulation of $\mathrm{Cd}$ in the roots occurs because the endodermis functions as a barrier to the radial transport of $\mathrm{Cd}$ in the root, thereby restricting its movement to the shoots (Hardiman et al., 1984). Other mechanisms of Cd-exclusion are also important in preventing the movement of $\mathrm{Cd}$ to the shoots. For example, Kabata Pendias and Pendias (1992)) stated that an increase in the uptake of cadmium mostly accumulates in the roots. The cadmium blockage in the roots probably involves formation of this metal bonding with sulfhydrol and with proteins forming so called phytochelatins. Also, Gondek and Filipek Mazur (2003) reported that most of Cd uptake by plant was retained in the roots, and consequently less $\mathrm{Cd}$ content was transported to the shoots it is possible that $\mathrm{Cd}$ might be immobilized by the negatively charged pectin within the cell wall, precipitated as insoluble $\mathrm{Cd}$ salts in the cell walls or 
intercellular spaces or crossed the plasma membrane, and sequestered in the vacuoles of rhizodermal and cortical cells (Lasat et al., 2002). These results are in harmony with those reported by El-Ghinbihi (2000) on common bean.

Addition of humic acid gradually decreased Cd taken up in roots, leaves and seeds of radish and bean plants compared to the control treatment. Humic acids significantly decreased $\mathrm{Cd}$ accumulation in radish and common bean plants in both seasons (Tables 10 and 11). The humic acid treatment reduced $\mathrm{Cd}$ contents in radish plants by (41.02 and 42.08, 25.54 and 25.38, 28.31 and $24.28 \%$ ) and in bean plants by (24.96 and 39.92, 36.39 and $37.3,43.61$ and $46.66 \%$ ) compared to control treatment in roots, leaves and seeds in the first and second seasons, respectively. The reduced bioavailability of metals in the presence of humic acids was believed to be due to competition for metals between complexing sites on humic acids and plants (Sunda and Huntsman 1998). Koukal et al. (2003) suggested that humic acids reduced metal toxicity in two different ways: (1) humic acids decrease the amount of free metal ions. Complexes of metal and humic acids are high molecular weight, relatively stable with regard to metal-exchange reactions and consequently the metals were less bioavailable. (2) humic acids adsorbed onto roots surfaces, shielded the cells from free metal ions.

The effects of the interaction between application rates of $\mathrm{Cd}$ and humic acid treatments on cadmium concentration of plant root, leaves and seeds were found significant for both plants in both seasons. The application of humic acid significantly decreased $\mathrm{Cd}$ concentration of roots, ,leaves, and dry seeds in both plants but with different magnitudes (Figures 20 and $22)$. At the highest cadmium application level (75ppm) data showed that the reduction in Cd concentration due to humic acid treatment application for radish plants were 35.5 and $37.63,31.26$ and $30.69 \%, 28.15$ and $25.5 \%$ compared to control in the first and second seasons respectively meanwhile the corresponding values in roots, leaves and seeds of common bean plants were 34.02 and $42.7,46.07$ and $47.17,36.67$ and $44.91 \%$ compared to control in the first and second seasons respectively. (figures 12 and 13). Fan et al. (2007) studied the change of species distribution of copper and cadmium in sediment through sequential extraction procedure and the results indicated that humic acids could stabilize heavy metals and reduce their bioavailability.

This variation in $\mathrm{Cd}$ uptake between radish and bean plants may be mainly attributed to crop species as reported by (Tiller, 1989)who stated that the accumulation of cadmium in plant biomass was not only affected by the soil properties, but by the crop species planted on the soil as well. For whole plants, the uptake of $\mathrm{Cd}$ by radish plants was higher comparing with the bean plants, indicating the sensitivity of bean plants to $\mathrm{Cd}$ than radish plants. Presently, at least 45 plant families comprising more than 400 species have been found to accumulate metals in their harvestable tissues, and the majority of them belong to the Brassicaceae family (Pal and Rai 2010). Also Cd was more affected in total chlorophyll and N,P and $\mathrm{k}$ contents of leaves of common bean than in radish plants which serves as an indication of the plant's potential metal tolerance (Frérot et al., 2010).

\section{Table 10. Cadmium content of roots, leaves, and seeds of radish plants as affected by different levels of cadmium and humic acid during the two growing seasons of 2010 and} 2011

\begin{tabular}{|c|c|c|c|c|c|c|c|}
\hline & & \multicolumn{2}{|c|}{$\begin{array}{l}\text { roots Cd content of } \\
\text { radish }(\mu \mathrm{g} / \mathrm{g} d w t)\end{array}$} & \multicolumn{2}{|c|}{$\begin{array}{l}\text { leaves Cd content of radish } \\
(\mu \mathrm{g} / \mathrm{g} d w \mathrm{t})\end{array}$} & \multicolumn{2}{|c|}{$\begin{array}{c}\text { seeds Cd content of } \\
\text { radish }(\mu \mathrm{g} / \mathrm{g} \mathrm{dwt})\end{array}$} \\
\hline & & $\begin{array}{c}2010 \\
\text { season }\end{array}$ & $\begin{array}{c}2011 \\
\text { season }\end{array}$ & $\begin{array}{c}2010 \\
\text { season }\end{array}$ & $\begin{array}{c}2011 \\
\text { season }\end{array}$ & $\begin{array}{c}2010 \\
\text { season }\end{array}$ & $\begin{array}{c}2011 \\
\text { season }\end{array}$ \\
\hline \multirow{4}{*}{ 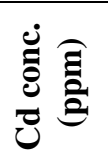 } & 0 & $60.90 \mathrm{D}$ & $62.68 \mathrm{D}$ & $48.16 \mathrm{D}$ & $45.56 \mathrm{D}$ & $21.21 \mathrm{D}$ & $20.20 \mathrm{D}$ \\
\hline & 25 & $474.50 \mathrm{C}$ & $469.68 \mathrm{C}$ & $138.00 \mathrm{C}$ & $134.85 \mathrm{C}$ & $74.38 \mathrm{C}$ & $66.23 \mathrm{C}$ \\
\hline & 50 & $666.67 \mathrm{~B}$ & $668 \mathrm{~B}$ & 168.50B & $168.84 \mathrm{~B}$ & $84.83 \mathrm{~B}$ & $78.21 \mathrm{~B}$ \\
\hline & 75 & $844.18 \mathrm{~A}$ & $835.30 \mathrm{~A}$ & $212.33 \mathrm{~A}$ & $213.31 \mathrm{~A}$ & $103.0 \mathrm{~A}$ & $98.41 \mathrm{~A}$ \\
\hline \multirow{2}{*}{ 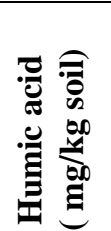 } & 0 & $643.54 \mathrm{~A}$ & $644.50 \mathrm{~A}$ & $162.5 \mathrm{~A}$ & $161.08 \mathrm{~A}$ & $82.54 \mathrm{~A}$ & $74.85 \mathrm{~A}$ \\
\hline & 150 & $379.58 \mathrm{~B}$ & $373.3 \mathrm{~B}$ & $121.0 \mathrm{~B}$ & $120.20 \mathrm{~B}$ & $59.17 \mathrm{~B}$ & $56.68 \mathrm{~B}$ \\
\hline
\end{tabular}

\footnotetext{
*Values having a common alphabetical letter (s), do not significantly differ, using the revised L.S.D. test at $\mathrm{P}=0.05$.
} 
Table11. Cadmium content of roots, leaves, and seeds of bean plants as affected by different levels of cadmium and humic acid during the two growing seasons of 2010 and 2011

\begin{tabular}{|c|c|c|c|c|c|c|c|}
\hline & & \multicolumn{2}{|c|}{$\begin{array}{c}\text { roots Cd content of bean } \\
(\mu \mathrm{g} / \mathrm{g} d w \mathrm{t})\end{array}$} & \multicolumn{2}{|c|}{$\begin{array}{l}\text { leaves } C d \text { content of } \\
\text { bean }(\mu \mathrm{g} / \mathrm{g} \mathrm{dwt})\end{array}$} & \multicolumn{2}{|c|}{$\begin{array}{c}\text { seeds Cd content of bean } \\
(\mu \mathrm{g} / \mathrm{g} \text { dwt })\end{array}$} \\
\hline & & $\begin{array}{c}2010 \\
\text { season }\end{array}$ & $\begin{array}{c}2011 \\
\text { season }\end{array}$ & $\begin{array}{c}2010 \\
\text { season }\end{array}$ & $\begin{array}{c}2011 \\
\text { season }\end{array}$ & $\begin{array}{c}2010 \\
\text { season }\end{array}$ & $\begin{array}{c}2011 \\
\text { season }\end{array}$ \\
\hline \multirow{4}{*}{ 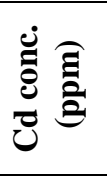 } & 0 & $34.7 \mathrm{D}$ & $30.94 \mathrm{D}$ & $19.53 \mathrm{D}$ & $18.59 \mathrm{D}$ & $5.11 \mathrm{D}$ & $4.57 \mathrm{D}$ \\
\hline & 25 & $281.33 \mathrm{C}$ & $251.23 \mathrm{C}$ & $87.33 \mathrm{C}$ & $85.40 \mathrm{C}$ & $9.9 \mathrm{C}$ & $10.12 \mathrm{C}$ \\
\hline & 50 & $371.58 \mathrm{~B}$ & $319.73 \mathrm{~B}$ & $134.05 \mathrm{~B}$ & $132.80 \mathrm{~B}$ & $18.59 \mathrm{~B}$ & $17.42 \mathrm{~B}$ \\
\hline & 75 & $508.23 \mathrm{~A}$ & $482.02 \mathrm{~A}$ & $146.30 \mathrm{~A}$ & $144.91 \mathrm{~A}$ & $24.85 \mathrm{~A}$ & $23.36 \mathrm{~A}$ \\
\hline \multirow{2}{*}{ 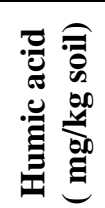 } & 0 & $341.24 \mathrm{~A}$ & $338.56 \mathrm{~A}$ & $148.9 \mathrm{~A}$ & $148.03 \mathrm{~A}$ & $18.69 \mathrm{~A}$ & $18.09 \mathrm{~A}$ \\
\hline & 150 & $256.08 \mathrm{~B}$ & 203.41 B & $94.71 \mathrm{~B}$ & $92.82 \mathrm{~B}$ & $10.54 \mathrm{~B}$ & $9.65 \mathrm{~B}$ \\
\hline
\end{tabular}

*Values having a common alphabetical letter (s), do not significantly differ, using the revised L.S.D. test at P=0.05.

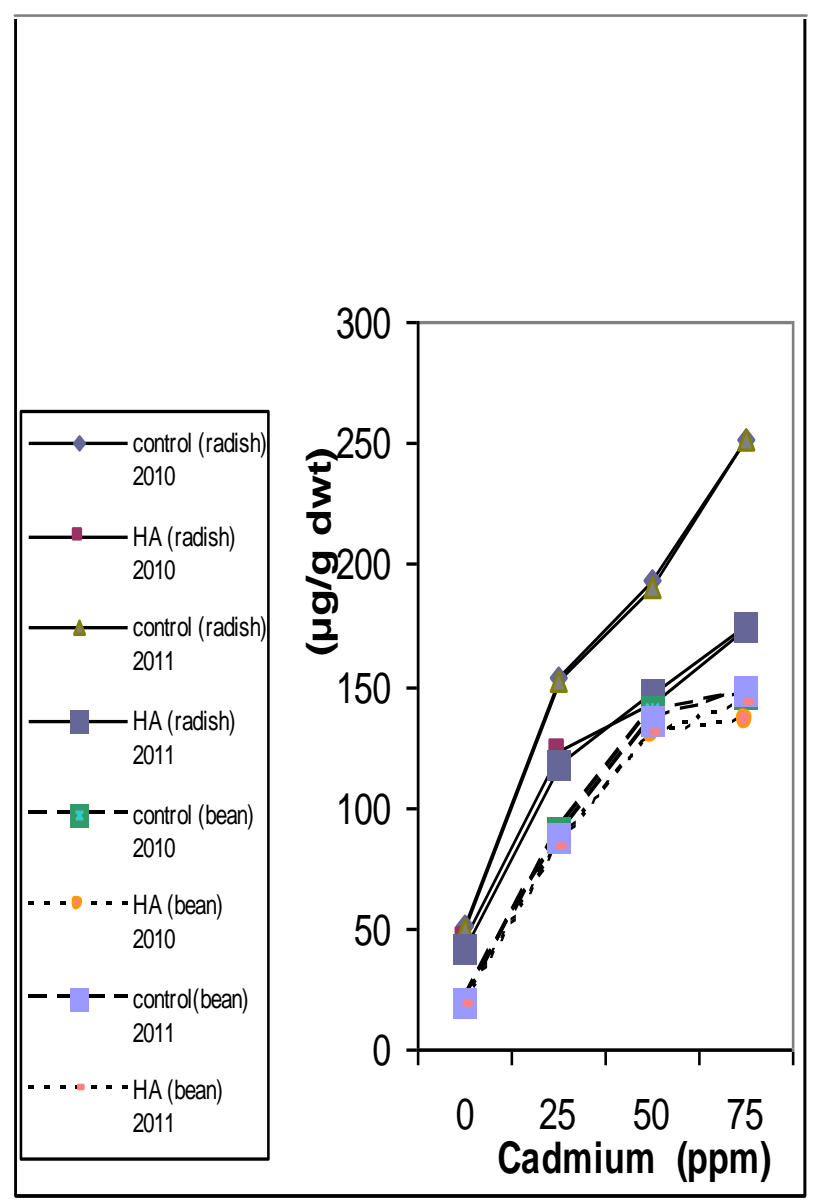

Figure 20. Interaction effect of cadmium and humic acid oncadmium content of roots of bean and radish plants during 2010 and 2011seasons.

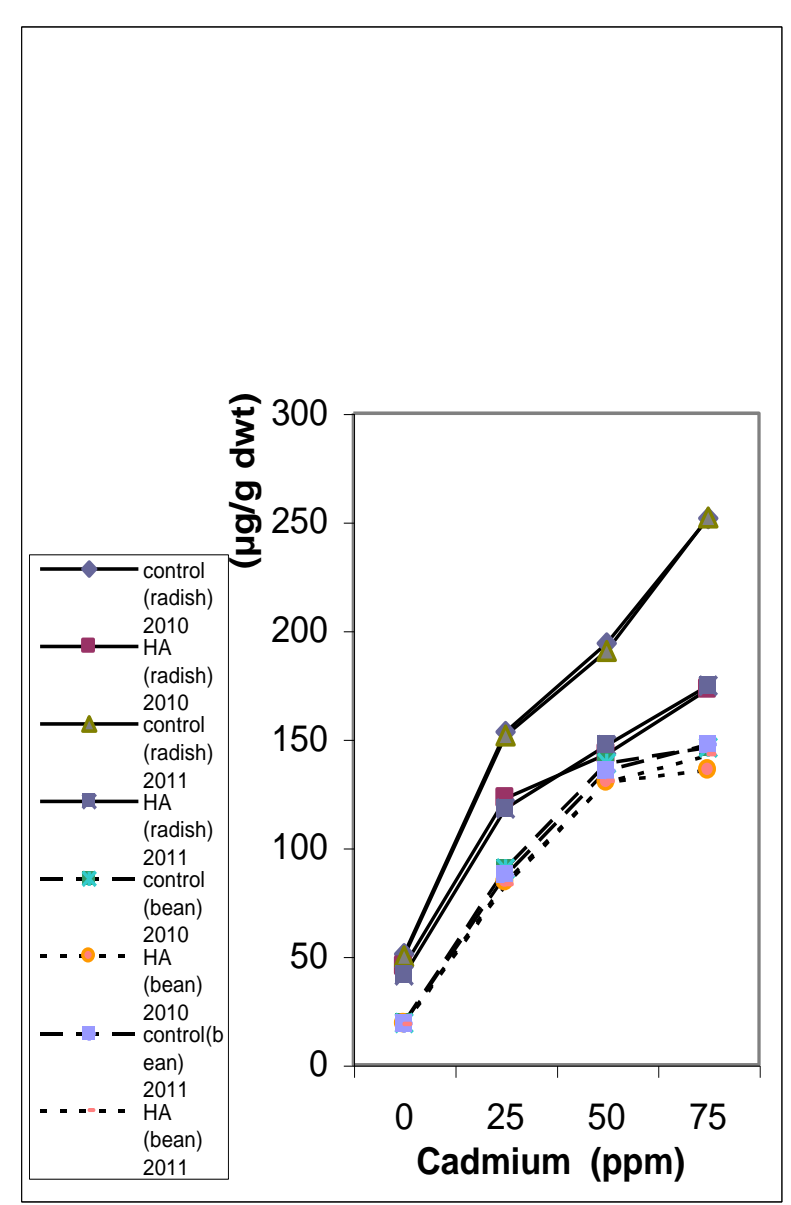

Figure 21. Interaction effect of cadmium and $h$ umicacid on cadmium content of bean and radish plants leaves during the two $g$ rowing seasons of 2010 and 2011. 


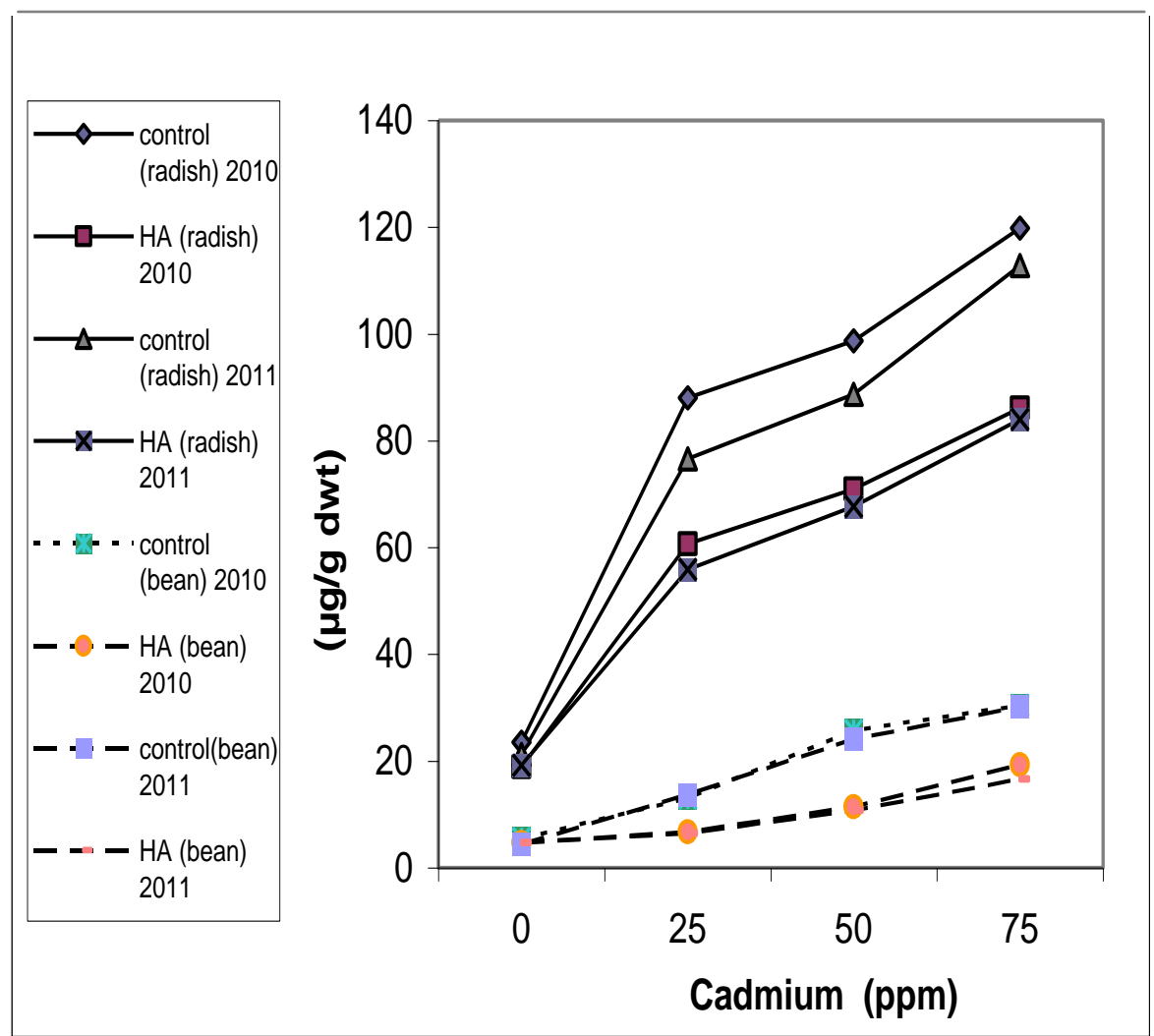

\section{Figure 22. Interaction effect of cadmium and humicacid on cadmium content of bean and radish seedsd during the two $\mathrm{g}$ rowing seasons of 2010 and 2011.}

\section{REFERENCES}

Al-Rawy, K.M. and A.M .Khalaf-allah. 1980. Design and analysis of Agricultural experiments. A Textbook. Elmousl Univ.press, Ninawa. Iraq. pp.487.

Abdel-Basset, R., A. Issa and M. Adam.(1995). Chlorophyllase activity: effects of heavy metals and calcium. Photosynthetica 31: 421-425.

Adani, F., Genevini, P., Zaccheo, P. and Zocchi G. (1998) The effect of commercial humic acid on tomato plant growth and mineral nutrition. J. Plant Nutr. 21:561-575.

Albayrak, S., and Camas N. (2005) Effects of different levels and application times of humic acid on root and leaf yield and yield components of forage turnip (Brassica rapa L.). J. Agron., 4(2): 130-133.

Andrade, F.V., Mendonca, E.S., Silva, I.R. and Mateus, R.F. (2004) Low molecular weightand humic acids increase phosphorus uptake and corn growth in Oxisoils. In HUMIC SUBSTANCES AND SOIL AND WATER ENVIRONMENT. p 211-214.

Barcelo, J., and Poschenrieder, C. (1990) Plant Water relations as affected by heavy metal stress: a review. J. Plant Nutrition. 13: 1-37.
Benavides, M.P., Gallego, S.M. and Tomaro, M.L. 2005. Cadmium toxicity in plants. Braz. J. Plant Physiol.17: 2134.

Brown, J. and O. Lilliand. 1946. Rapid determination of potassium and sodium in plant material and soil extracts of flame-photometry. Proc. Amer. Soc. Hort. Sci.48: 341346.

Champman, D. H. and F.P. Pratt. 1978. Methods of analysis for soil, plants and waters. Univ. of California Div., Agric., priced publication, 4034.p.50 and 169.

Chandra, Ch. Shekar, D. Sammaiah, M. Rambabu and K. Jaganmoha Reddy. 2011. Effect of cadmium on tomato growth and yield attributes. J. Microbiol. Biotech. Res. 3:109-112.

Chen, B., and Zhu, Y.G. (2006) Humic acids increase the phytoavailability of $\mathrm{Cd}$ and $\mathrm{Pb}$ to wheat plants cultivated in freshly spiked, contaminated soil. J. of Soils and Sediments, 6(4): 236-242.

Chen, Y. and Aviad, T. (1990) Effects of humic substances on plant growth. In, MacCarthy, P., Clapp, C.E., Malcplm, R.L. and Bloom, P.R. (eds), Humic substances in Soil and Crop sciences, Selected readings.ASA and ASSSA, Madison, WI. Pp 161-186. 
Chen, Y.X., Y.F. He, Y.M. Luo, Y.L. Yu, Q. Lin and M.H. Wong, 2003. Physiological mechanism of plant roots exposed to cadmium. Chemosphere. 50: 789-793.

Cottenie, A., M. Verloo, G. Velgh, L. Kiekens and R. Camcrlynck. 1982. Chemical analysis of plant and soils. Lab. of Analytical and Agro. State Univ. Ghent -Belgium.

Dursun, A., I. Guveno and M. Turan, 2002. Effects of different levels of humic acid on seedling growth and macro- and micro-nutrient contents of tomato and eggplant. ACTA Agrobotanica, 56: 81-88.

El-Ghinbihi, F.H. 2000. Growth, chemical composition and yield in some common bean varieties as affected by different cadmium and lead levels. Minufiya J. Agric. Res. 25: 603-625.

Fan W., Chen J., Wang Q. (2007) Influence of humic acid on species of heavy metals in sediment. Environ Chem 26:224.

Fayed A.M. (1997). Evolution of some cultivars and mutants of cow pea (Vigna unguiculata L.) under Kafr EL Sheikh condition M.Sc. Thesis. Fac. Agric, Kafr EL-Sheikh, Tanta. University.

Fouda, R.A. and A.A. Arafa, 2002. Alleviation of cadmium toxicity on soybean, Glycine max (L.)Merr. by inoculation with Bradyrhizobium and vesicular-arbuscular mycorrhizae or kinetin. J. Agric. Sci. Mansoura Univ. 27(11): 7385-7403.

Frérot, H., Faucon M., Willems, G, Godé, C, Courseaux, A, Darracq, A, Verbruggen,N, \& Saumitou-laprade, P. (2010). Genetic architecture of zinc hyper accumulation in Arabidopsis halleri : the essential role of QTL $x$ environment interactions. New Phytol. , 187: 355-367.

Gadallah, M.A.A., 1995. Effect of cadmium and kinetine on chlorophyll content, saccharides and dry matter accumulation in sunflower plants. Biol. Plant. 37: 233240.

Gondek, K. and B. Filipek Mazur (2003). Biomass yield of shoots and roots of plants cultivated in soil amended by vermi composts based on tannery sludge and content of heavy metals in plant tissues. Plant Soil Environ. 49(9): 402409.

Hardiman, R., A.Banin and B.Jacoby .(1984). The effect of soil type and degree of metal contamination on uptake of $\mathrm{Cd}, \mathrm{Pb}$ and $\mathrm{Cu}$ in bush beans (Phaseolus vulgaris $\mathrm{L}$ ). Plant and soil. 81 (1): 3-15.

Hartwigsen J.A., Evans M.R. 2000. Hu-mic acid seed and substrate treatments promote seedling root development. HortScience: 35 (7): 1231-1233.

IARC, 1994. Beryllium, cadmium, mercury, and exposures in the glass manufacturing industry[M]. In: Monographs on the evaluation of carcinogenic risks to humans. Lyon: WHO Press. 58: 444.

Jackson, M. L., 1973. Soil chemical analysis. Verlag. Prentia. Hall inc., Englewood. Cliffs, USA.

Kabata-Pendias A., Pendias H. 1992. Trace elements in soils and plant. 2 nd ed. CRC Press inc., Boca Raton, FL, USA.p 365 .
Karakurt Y, Unlu H, Unlu H, Padem H (2009). The influence of foliar and soil fertilization of humic acid on yield and quality of pepper. Acta Agric. Scand. Sec. B - Plant Soil Sci. 59:233-237.

Khan D.H., B. Frankland,1983. Effects of cadmium and lead on radish plants with particular reference to movement of metals through soil profile and plant. Plant Soil. 7: 335-345.

Koukal, B., Gueguen C., Pardos M., Domonik J. (2003). Influence of humic substances on the toxic effects of cadmium and zinc to the green algae Pseudokirchneriella subcapitata. Chemosphere 53:8 p. 953-961..

Lasat, M.M. (2002). Phytoextraction of toxic metals: a review of biological mechanisms.J. Environ Qual. 31: 109-120.

Ling , E .R. 1963. Determination of total nitrogen by semimicro Kjeldahl method. Dairy Chem. 11: 23-84.

Mallikarjuna, Rao M., Govindasamy, R.and Chandrasekaran, S. (1987) Effect of Humic acid on Sorghum vulgare var. CSH-9. Current science. 56 (24) $: 1273$.

Mato, M.C., Olmedo, M.G. and Mendez, J. (1972) Inhibition of indoleacetic acid oxidase by soil humic acids fractionated on sephadex. Soil Biology and Biochemistry. 44: 469-473.

Murillo, J.M., Madejon, E., Madejon, P. and Cabrera, F. (2005) The response of wild olive to the addition of a fulvic-rich acid amendment to soils polluted by trace elements. Journal of Arid Environments, London. 63: 284-303.

Ohta, K., Morishita, S., Suda, K., Kobayashi, N. and Hosoki, T. (2004) Effects of chitosan soil mixture treatment in the seedling stage on the growth and flowering of several ornamental plants. J. Japan. Soc. Hort. Sci. 73(1): 66-68.

Page, A.L., R.H. Miller and D.R Keeneny. 1982. Methods of soil analysis. Part 2. chemical and microbiological properties. $2^{\text {nd }}$ edition. Agron. Madison, Wisconsin, USA.

Pal, R., and Rai, J. P. N. (2010). Phytochelatins: peptides involved in heavy metal detoxification. Appl. Biochem. Biotechnol. , 160: 945-963.

Pettit R.E. (2004). Organic matter, humus, humate, humic acid, fulvic acid and humin: their importance in soil fertility and plant health [Online]. Available at www.humate.info/mainpage.htm.

Raina, J.N. and Goswami, K.P. (1988) Effect of fulvic acid and fulvates on the growth and nutrient uptake by maize plant. J. Indian Soc. Soil Sci. 36: 264-268.

Rosa, C.M., Castilhos, R.M.V., Vahl, L.C. and Costa, P.F.P. (2004) Effect of fulvic acids on plant growth, root morphology and macronutrient uptake by oats. In HUMIC SUBSTANCES AND SOIL AND WATER ENVIRONMENT. p 207-210.

Samson, G. and Visser, S.A. (1989) Surface-active effect of humic acids on potato cell membrane properties. Soil Biology Biochemistry, Bern. 21;343-347. 
Sandalio L.M., Dalurzo HC, Gomez M, Romero-Puertas MC, del Río LA (2001) Cadmium-induced changes in the growth and oxidative metabolism of pea plants. J. Exp. Bot. 52:2115-2126.

SAS. 1996. Software program. Cary, North Carolina State. Univ., Karl M Glsener. USA.

Sheoran, I.S., Aggarwal, N. and Singh, R. (1990) Effect of cadmium and nickel on in vivo carbon dioxide exchange rate of pigeon pea (Cajianus cajas L.). Plant Soil. 129: 243-249.

Somashekaraiah B.V., Padmaja K, Prasad ARK (1992) Phytotoxicity of cadmium ions on germinating seedlings of mung bean (Phaseolus vulgaris): involvement of lipid peroxides in chlorophyll degradation. Physiol. Plant. 85:85-89.

Stevenson, F. J. 1994. Humus chemistry- Genesis, Composition, Reactions. John Wiley \& Sons, Inc., New York.
Sunda, W.G. and S.A. Huntsman, 1998. Process regulating cellular metal accumulation and physiological effects: Phytoplankton as model systems. Sci. Total Environ., 219: 165-181.

Thomas, R.M. and V.P.Singh .(1996).Reduction of cadmiuminduced inhibition of chlorophyll and carotenoid accumulation in Cucumis sativus L. by uniconazole (S 3307). Photosynthetica . 32:145-148.

Tiller K.G. (1989) Heavy metals in soils and their environmental significance. Advances in Soil Science 9, 114-142.

Varalakshmi, L. R. and A.N. Ganeshamurthy,A.N. (2013). Phytotoxicity of Cadmium in Radish and Its Effects on Growth, Yield, and Cadmium Uptake. communication in soil science and plant analysis.44( 9): 1444-1456

Wahid, A., A. Ghani and F. Javed, 2008. Effect of cadmium on photosynthesis, nutrition and growth of mung bean. Agron. Sustain. Dev. 28: 273-280.

Wahid, A., A. Ghani, I. Ali and M.Y. Ashraf, 2007. Effects of cadmium on carbon and nitrogen assimilation in shoots of mungbean [Vigna radiata L.) Wilczek seedlings. J. Agron. Crop Sci. 193: 357-365. 
282

ALEXANDRIA SCIENCE EXCHANGE JOURNAL, VOL. 34, No.2 APRIL-JUNE 2013

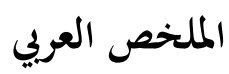

تأثير اضافة حمض الهيوميك فى تقليل الاثار الضارة للكادميوم على نباتات الفجل والفاصوليا

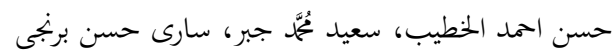

للفجل كذلك الخصول للفاصوليا مقارنة بالكنترول. أيضا أدت زيادة

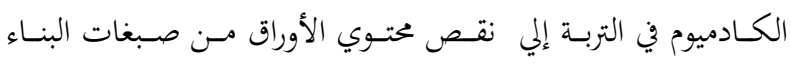

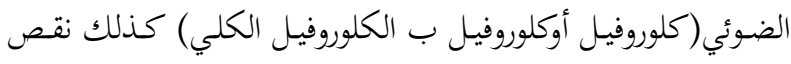

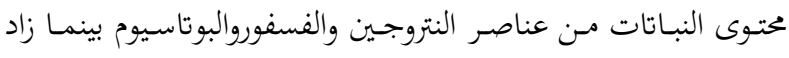
عتوي النباتات من الكادميوم بزيادته في التزبة وكان تركيز الكادميوم

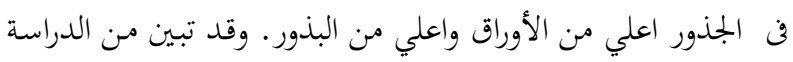
أن الفاصوليا أكثر حساسية من الفجل لزيادة تركيز الكادميوم في التربة الكادية

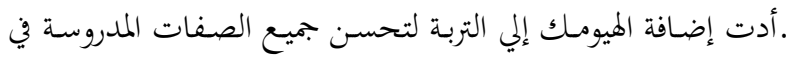

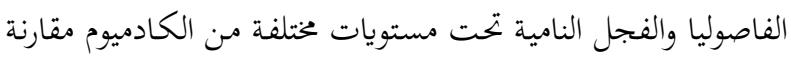
بالكنترول كذلك خفضت محتوي النبات من الكادميوم.
أجريت التجربة باستخدام أصص خلال موسمي الصيف 2010

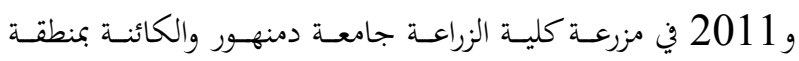

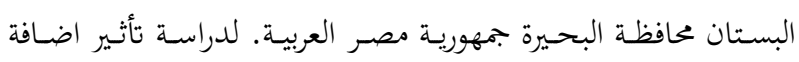

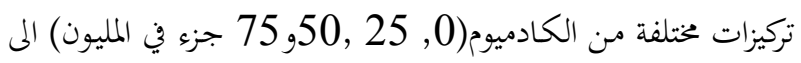

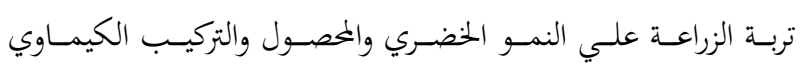

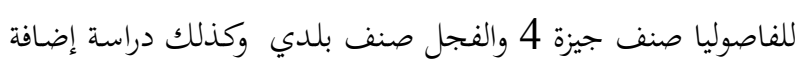

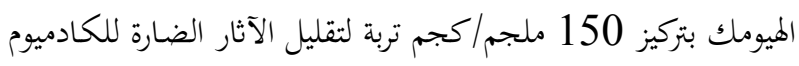

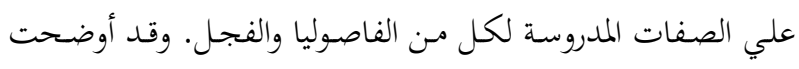

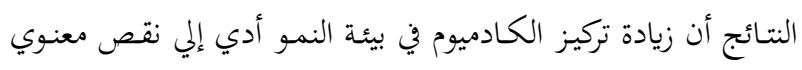

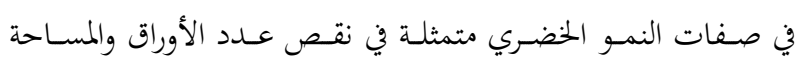

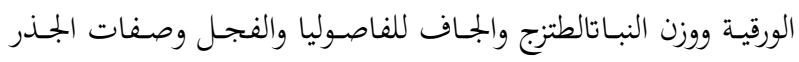

